\title{
SPATIOTEMPORAL AND FUNCTIONAL CHARACTERISATION OF TRANSIENT RECEPTOR POTENTIAL VANILLOID 4 (TRPV4) IN THE MURINE INTERVERTEBRAL DISC
}

\author{
M.K.M. Kim ${ }^{1,2}$, R. Ramachandran ${ }^{1,2}$ and C.A. Séguin ${ }^{1,2, *}$ \\ ${ }^{1}$ Department of Physiology and Pharmacology, Schulich School of Medicine and Dentistry, \\ The University of Western Ontario, London, Ontario, N6A 5C1, Canada \\ ${ }^{2}$ Bone and Joint Institute, The University of Western Ontario, London, Ontario, N6A 5C1, Canada
}

\begin{abstract}
The molecular regulators of mechano-transduction in intervertebral disc (IVD) cells are not well understood. The aim of the present study was to characterise the expression and function of the mechano-sensitive ion channel TRPV4 in the IVD. A novel transgenic reporter mouse, in which the endogenous Trpv4 locus drove the expression of LacZ, was used to localise Trpv4 expression at specific stages of spine development [embryonic day (E) 8.5, 12.5, 17.5, postnatal day 1] and time points following skeletal maturity $(2.5,6,9$ and 12 months). The TRPV4-specific agonist GSK1016790A and antagonist GSK2193874 were used to assess the functional response of annulus fibrosus (AF) cells using epifluorescence imaging with $\mathrm{Ca}^{2+}$-sensitive Fura-2 dye and F-actin staining. The effects of TRPV4 agonism and antagonism in mechanically stimulated AF cells were quantified by gene expression analysis. Trpv 4 expression was specific to the developing notochord and intervertebral mesenchyme at E12.5. At 2.5, 6 and 9 months, Trpv4 expression was detected in the nucleus pulposus, inner AF, cartilage endplate and vertebral growth plate. AF cells treated with GSK1016790A demonstrated heterogeneity in TRPV4-dependent $\mathrm{Ca}^{2+}$ responses (no response, calcium oscillation or sustained response). TRPV4-induced $\mathrm{Ca}^{2+}$ signalling was associated with Rho/ROCK-dependent actin cytoskeleton remodelling and stress-fibre formation. In AF cells, cyclic-tensile-strain-induced changes in Acan and Prg4 expression were mediated by TRPV4 channel activation. These data establish TRPV4 as an important mechanosensor regulating IVD mechano-biology.
\end{abstract}

Keywords: Intervertebral disc, transient receptor potential vanilloid 4, mechano-transduction, nucleus pulposus, annulus fibrosus, cyclic tensile strain.

*Address for correspondence: Dr Cheryle A. Séguin, Department of Physiology and Pharmacology, Schulich School of Medicine and Dentistry, The University of Western Ontario, London, Ontario, N6A 5C1, Canada. Email: cheryle.seguin@schulich.uwo.ca

Copyright policy: This article is distributed in accordance with Creative Commons Attribution Licence (http://creativecommons.org/licenses/by-sa/4.0/).

\begin{tabular}{|c|c|c|c|}
\hline & List of Abbreviations & Cxcl1 & chemokine (C-X-C motif) ligand 1 \\
\hline & & DAPI & 4',6-diamidino-2-phenylindole \\
\hline Acan & aggrecan & DMEM/F12 & Dulbecco's-modified Eagle medium/ \\
\hline Acta2 & actin $\alpha 2$ & & Ham's F-12 medium \\
\hline ADAMTS4 & a disintegrin and metalloproteinase & DMSO & dimethyl sulphoxide \\
\hline & with thrombospondin motifs 4 & ECM & extracellular matrix \\
\hline $\mathrm{AF}$ & annulus fibrosus & EGTA & ethylene glycol-bis $(\beta$-aminoethyl \\
\hline $\mathrm{AKT}$ & protein kinase B & & ether)-N,N,N',N'-tetraacetic acid \\
\hline BSA & bovine serum albumin & ERK1/2 & extracellular-signal-regulated kinase \\
\hline CaMKII & $\mathrm{Ca}^{2+} /$ calmodulin-dependent protein & & $1 / 2$ \\
\hline & kinase II & Fap & fibroblast activation protein $\alpha$ \\
\hline Cilp & cartilage intermediate layer protein & FBS & foetal bovine serum \\
\hline Col1a1 & type I collagen & FRT & flippase recognition target \\
\hline Col2a1 & type II collagen & Gdf10 & growth differentiation factor 10 \\
\hline CTS & cyclic tensile strain & IAF & inner AF \\
\hline
\end{tabular}




\begin{tabular}{|c|c|}
\hline IVD & intervertebral disc \\
\hline JNK1/2 & Jun N-terminal kinase1/2 \\
\hline HEPES & $\begin{array}{l}\text { 4-(2-hydroxyethyl)-1- } \\
\text { piperazineethanesulphonic acid }\end{array}$ \\
\hline Hprt & $\begin{array}{l}\text { hypoxanthine quinine } \\
\text { phosphoribosyl transferase }\end{array}$ \\
\hline Mip1 $\alpha$ & $\begin{array}{l}\text { macrophage inflammatory protein } \\
1 \alpha\end{array}$ \\
\hline MMPs & matrix metalloproteinases \\
\hline NP & nucleus pulposus \\
\hline p27 Kip1 & cyclin-dependent kinase inhibitor $1 \mathrm{~B}$ \\
\hline Pax1 & paired box 1 \\
\hline PBS & phosphate-buffered saline \\
\hline $\operatorname{Pgc} 1 \alpha$ & $\begin{array}{l}\text { peroxisome proliferator-activated } \\
\text { receptor gamma coactivator } 1 \alpha\end{array}$ \\
\hline PN & postanal \\
\hline $\operatorname{Prg} 4$ & lubricin \\
\hline RGD & Arg-Gly-Asp \\
\hline ROCK & Rho-associated protein kinase \\
\hline ROI & region of interest \\
\hline TAZ & PDZ-binding motif \\
\hline TRPV4 & transient receptor potential vanilloid \\
\hline $\begin{array}{l}4 \\
\text { WT }\end{array}$ & wild type \\
\hline YAI & Yes-associated protein \\
\hline
\end{tabular}

\section{Introduction}

Low-back pain, one of the leading causes of disability worldwide (James et al., 2017), is often associated with IVD degeneration (Arnbak et al., 2016). The lack of disease-modifying treatments for IVD degeneration is associated with an incomplete understanding of the cellular pathways that contribute to disc development, function and degeneration. The IVD is a fibrocartilaginous connective tissue structure located between the vertebral bodies responsible for spine load bearing and movement. IVDs are composite structures consisting of distinct tissue types that work in concert to absorb and dissipate mechanical load throughout the spine. During axial load, the central NP, due to its high water content, experiences compressive and hydrostatic loading, creating an intradiscal pressure that deforms the outer AF, which in turn experiences multi-directional tensile strain (Adams et al., 1996; Gregory and Callaghan, 2011; Neidlinger-Wilke et al., 2014; ShiraziAdl et al., 1984).

Similar to other musculoskeletal tissues, biomechanical factors are important contributors to the IVD microenvironment and play a role in both tissue homeostasis and initiation of disc degeneration (Gawri et al., 2014a; Iatridis et al., 2006; Setton and Chen, 2004; Videman and Nurminen, 1990). Specifically, physiological levels of mechanical load produce an anabolic response in the IVD marked by increased expression of ECM genes, such as aggrecan and collagen, and decreased expression of catabolic enzymes, such as MMPs (Chan et al., 2011; Neidlinger-Wilke et al., 2005; Walsh and Lotz, 2004; Wuertz et al., 2007b; Wuertz et al., 2009). In contrast, aberrant mechanical loading (either under- or overloading) can contribute to altered ECM homeostasis through the initiation of tissue degeneration (Gawri et al., 2014b; Iatridis et al., 2006; Videman and Nurminen, 1990). Despite numerous studies characterising the effects of mechanical stimulation on IVD tissues, information regarding the mediators of IVD mechano-transduction - i.e. how cells sense mechanical forces and convert them into biochemical signals - remains limited.

Previous reports on the mechano-sensing mechanism in AF cells have focused on the role of integrins as mechano-receptors. Expression profiling of integrin subunits in the human IVD shows tissuetype and regional variation in their expression pattern. Notably, the RGD-integrin $\alpha 5 \beta 1$ is highly expressed in human NP and IAF cells, compared to the outer AF (Nettles et al., 2004), and mediates the cellular response to mechanical loading (Gilbert et al., 2013; Kurakawa et al., 2015; Le Maitre et al., 2009). Exposure of non-degenerate human NP cells to compressive load (0.35-0.95 MPa, $1 \mathrm{~Hz}$ for $2 \mathrm{~h}$ ) decreases Acan expression, which is inhibited by cell pre-treatment with an RGD peptide to block integrin ligand binding. However, this effect is not detected in NP cells derived from degenerative human IVDs (Le Maitre et al., 2009). In non-degenerate human AF cells exposed to CTS (10\% tension, $1.0 \mathrm{~Hz}$ for $20 \mathrm{~min}$ ) pre-treatment with RGD peptide prevents the mechanically induced decrease in ADAMTS4 expression and increases focal adhesion kinase phosphorylation. Similar to NP cells, the RGD pretreatment fails to inhibit the mechano-response in degenerate AF cells (Gilbert et al., 2013). These findings suggest that IVD mechano-transduction pathways and effectors of mechano-response vary depending on cell type and degenerative state. To date, however, the role and expression pattern of other mechano-receptors in the IVD have not been fully elucidated.

The TRPV4 channel is a multi-modally activated $\mathrm{Ca}^{2+}$-permeable non-selective cation channel involved in transducing various environmental cues into specific cellular responses by generating intracellular $\mathrm{Ca}^{2+}$ transients (Strotmann et al., 2000; Watanabe et al., 2003). In mammals, TRPV4 was first reported to regulate cellular functions in response to changes in osmolarity in murine heart, liver and kidney (Liedtke et al., 2000; Liedtke and Kim, 2005; Strotmann et al., 2000). In porcine chondrocytes, chemical and mechanical activation of TRPV4 regulates the expression of type II collagen and transforming growth factor $\beta 3$ genes ( $\mathrm{O}^{\prime}$ Conor et al., 2014). Furthermore, studies using mice with global deletion of Trpo4 showed that mechanically regulated bone formation and resorption (Mizoguchi et al., 2008) as well as mechanically induced intracellular $\mathrm{Ca}^{2+}$ 
oscillation in osteoblasts are also TRPV4-dependent (Suzuki et al., 2013).

Recent studies have identified candidate signalling pathways downstream of TRPV4 activation. In murine epidermal keratinocytes, Trpv4 deletion inhibits matrix stiffness-induced nuclear translocation of YAP and transcriptional coactivator TAZ as well as phosphorylation of $\mathrm{AKT}$, pathways known to regulate epithelial-mesenchymal transition (Sharma et al., 2019). TRPV4-mediated activation of AKT has also been reported to control cell proliferation in human breast cancer cells by driving cytoplasmic localisation of the cell cycle inhibitor p27kip1, leading to $S$ phase entry (Nam et al., 2019). In murine 3T3-F442A adipocytes, TRPV4 activation induces phosphorylation of ERK $1 / 2$ as well as JNK1/2 and TRPV4-induced ERK1/2 phosphorylation is necessary for TRPV4-mediated regulation of $\mathrm{Pgcl}_{\mathrm{g}} \alpha$, Mip1 $\alpha$ and Cxcl1 expression (Ye et al., 2012). In addition, pharmacological activation of TRPV4 in osteoblasts increases phosphorylation of CaMKII in a differentiation-dependent manner associated with increased expression of TRPV4 during osteoblastic differentiation (Hu et al., 2019). Collectively, these studies provide evidence for TRPV4 being an important regulator of cellular processes, mediating intracellular signalling pathways in a cell-type- and context-dependent manner.

Using a bovine ex vivo IVD organ culture model, Walter et al. (2016) showed thatreduced tissue osmolarity increases TRPV4 protein expression and channel activation, which correlates with increased interleukin-1 $\beta$ and interleukin- 6 gene expression in IVD cells . Furthermore, Kim et al. (2020) showed increased Trpv4 expression in murine AF cells following acute exposure to CTS $(6 \%$ tension, $2.0 \mathrm{~Hz}$ for $30 \mathrm{~min})$. However, the in situ expression pattern of TRPV4 and its role in transducing and regulating the IVD mechano-response is unclear.

The goal of the present study was to characterise the expression and function of TRPV4 in murine IVD. Using a novel Trpv4 reporter mouse model, the study resolved the spatiotemporal expression profile of Trpv4 during murine embryonic spine development and ageing. Using both pharmacological and mechanical assays, the role of TRPV4 in AF cells was studied through the in vitro assessment of intracellular calcium response, cytoskeletal adaptation and changes in gene expression.

\section{Materials and Methods}

\section{Mice}

All experiments were performed in accordance with the policies and guidelines of the Canadian Council on Animal Care and approved by the Animal Use Subcommittee of the University of Western Ontario (protocol 2017-154). The EUCOMM "knockoutfirst" gene trap strategy was used to generate
Trpv $4^{t m 1 a(K O M P) W t s i}$ mice. Embryonic stem cells with the Trpv $4^{t m 1 a(\text { КОмP)Wtsi }}$ allele from Wellcome Trust Sanger Institute (produced for the Knockout Mouse Project; MGI: 4460277) were injected into C57BL/6NCrl host blastocysts. The resultant chimaeric offspring contained the L1L2_Bact_P cassette inserted upstream of exon 6 in the Trpo 4 locus. The cassette included 2 FRT sites flanking an IRES:LacZ trapping cassette and a floxed human $\beta$-actin-promoter-driven neo cassette inserted upstream, with an additional loxP site downstream of exon 6, the critical exon (Fig. 1a).

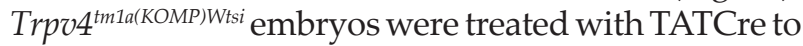
remove the neomycin resistance cassette and exon 6, to generate the Trpv $4^{t m 1 b(K O M P) W t s i}$ reporter mice, where the Trpv4 locus drove LacZ expression (Trpv4 $4^{\text {LacZ/LacZ; }}$ Fig. 1a). Wild-type C57BL/6N mice (Charles River) were used for gene expression analysis and cell culture experiments. Mice were housed in standard cages under a $12 \mathrm{~h}$ light/dark cycle, with rodent chow and water available ad libitum. Mice were euthanised by $\mathrm{CO}_{2}$ asphyxiation or by lethal injection of sodium pentobarbital.

For fate mapping experiments, male Trpv $4^{\text {LacZ/LacZ }}$ mice were mated with female wild-type C57BL/6N mice to generate $\operatorname{Trpv} 4^{\mathrm{Lac} Z / W T}$ mice. For timed mating, insemination was confirmed by the presence of vaginal sperm plug, which was counted as embryonic day (E) 0.5. Pregnant female mice were sacrificed at E8.5, E12.5 and E17.5 to harvest embryos. Thoracic, lumbar and caudal spines were isolated by dissection from mice 2.5, 6, 9 and 12 months old.

$\mathrm{NP}$ and AF tissues were isolated by microdissection from the lumbar and caudal spines of $\mathrm{C} 57 \mathrm{BL} / 6 \mathrm{~N}$ mice $2.5,6,9$ and 12 months old and immediately placed in TRIzol reagent (Life Technologies) for subsequent RNA extraction.

\section{$\beta$-galactosidase staining}

Embryos were fixed for $40 \mathrm{~min}(\mathrm{E}<10.5)$ or $1 \mathrm{~h}$ (E $>10.5$ ) on ice in $2 \%$ paraformaldehyde, $0.2 \%$ glutaraldehyde, $0.02 \%$ Igepal CA-630 in PBS. Embryos were washed in detergent rinse buffer $\left(0.01 \%\right.$ sodium deoxycholate, $2 \mathrm{mmol} / \mathrm{L} \mathrm{MgCl}_{2^{\prime}}$ $0.02 \%$ Igepal CA-630) for 3 times 10 min each prior to overnight incubation at $37{ }^{\circ} \mathrm{C}$ under agitation (VWR Scientific, Sheldon Manufacturing, Orbital Shaking Incubator, model number 1575) in X-gal staining solution $\left[1 \mathrm{mg} / \mathrm{mL}\right.$ X-gal, $2 \mathrm{mmol} / \mathrm{L} \mathrm{MgCl}_{2^{\prime}}$ $5 \mathrm{mmol} / \mathrm{L}$ EGTA, $0.02 \%$ Igepal CA-630, $5 \mathrm{mmol} / \mathrm{L}$ $\left.\mathrm{K}_{3} \mathrm{Fe}(\mathrm{CN})_{6}, 5 \mathrm{mmol} / \mathrm{L} \mathrm{K}_{4} \mathrm{Fe}(\mathrm{CN})_{6}\right]$. Then, embryos were washed 3 times in PBS (10 min each) and stored in PBS overnight to allow stain to develop. Embryos were imaged using a Leica M165FC stereomicroscope (Leica Microsystems Inc.) and the staining reaction was stopped by placing embryos in $4 \%$ paraformaldehyde overnight at room temperature (post-fixed).

To visualise $\beta$-galactosidase staining in embryos $>$ E10.5 (including PN day 1; PN1), a clearing step was performed as previously described (McCann et al., 
2012; Schatz et al., 2005). Briefly, embryos were cleared using a series of solutions containing decreasing $\mathrm{KOH}$ and increasing glycerol concentrations (100:0, $80: 20,50: 50,20: 80$ and $0: 100$, respectively, for $3 \mathrm{~d}$ each) following post fixation. $\beta$-galactosidase staining of isolated thoracic, lumbar and caudal spinal segments was conducted as outlined above for mice $>2.5$ months old. Following staining, tissues were decalcified using Shandon's TBD-2 (Thermo Fisher Scientific) for $5 \mathrm{~d}$ at room temperature under continuous agitation (VWR Analog Rocking Platform Shaker, 2 tier, 120V, model number NO10127-876).

\section{Histology}

For histological analysis, tissues were dehydrated in a graded series of ethanol, cleared in xylene and embedded in paraffin wax, as previously described (McCann et al., 2012). Paraffin-wax-embedded samples were sectioned sagittally at a thickness of $5 \mu \mathrm{m}$. Mid-sagittal sections of whole embryos and spinal regions of skeletally mature mice (thoracic, lumbar and caudal) were counterstained with Eosin Y (Sigma-Aldrich) and mounted using DAKO Faramount aqueous mounting medium (DAKO/ Agilent). Embryo sections were imaged using BioTek Cytation 5 Cell Imaging Multi-Mode Reader and BioTek Gen5 Microplate Reader and Imaging Software (BioTek, Winooski, VT, USA). Spine sections were imaged using a Leica DM1000 Microscope with Leica Application Suite Software.

\section{Immunofluorescence}

Heat-induced antigen retrieval was performed in sodium citrate buffer $(10 \mathrm{mmol} / \mathrm{L}$ sodium citrate, $0.05 \%$ Tween-20, $\mathrm{pH}$ 6.0) at $95{ }^{\circ} \mathrm{C}$ for $12 \mathrm{~min}$ and tissue sections were blocked for $1 \mathrm{~h}$ with $5 \%$ goat serum in PBS containing $0.1 \%$ Triton X-100 (SigmaAldrich). Tissue sections were incubated with a primary antibody directed against $\beta$-galactosidase ( 1 : 500 in blocking solution; Abcam, ab616) in a humidified chamber overnight at $4{ }^{\circ} \mathrm{C}$. The next day, slides were washed with PBS-0.1 \% Triton X-100 and tissue sections were incubated with goat anti-rabbit Alexa Fluor 488 secondary antibody (1 : 500 in PBS; Thermo Fisher Scientific, A27034) for $1 \mathrm{~h}$, washed 3 times in PBS, coverslipped using Fluoroshield Mounting Medium with DAPI (Abcam) and imaged using the BioTek Cytation 5.

\section{Primary cell isolation and culture}

AF tissues were isolated by microdissection from 2.5 months old C57BL/6N mice (cervical to caudal spines) using the Fluorescent Stereo Microscope Leica M165 FC. Isolated tissues were digested for $20 \mathrm{~min}$ at $37^{\circ} \mathrm{C}$ using type II collagenase $(3 \mathrm{mg} / \mathrm{mL}$; Worthington Biochemical Corporation, Lakewood, NJ, USA) in DMEM/F12. Then, AF tissues were minced and further digested for $1 \mathrm{~h}$ at $37^{\circ} \mathrm{C}$. Tissue digests were filtered using a $70 \mu \mathrm{m}$ cell strainer and cells were pelleted by centrifugation $(237 \times g$ for $5 \mathrm{~min}$ ). Cells were plated at $37^{\circ} \mathrm{C}$ and $5 \% \mathrm{CO}_{2}$ in a humidified atmosphere at an initial density of $\sim 400,000$ cells $/ \mathrm{cm}^{2}$ in DMEM/F12 supplemented with $10 \%$ FBS and $1 \%$ penicillin and streptomycin (Thermo Fisher Scientific). Medium was changed every $2 \mathrm{~d}$ until cells reached $80 \%$ confluency.

All cell culture experiments were conducted using primary AF cells at passage 1. Cells were treated with the following compounds: TRPV4 antagonist GSK2193874 (Sigma-Aldrich), TRPV4 agonist GSK1016790A (Sigma-Aldrich) and pan ROCK inhibitor Y-27632 (STEMCELL Technologies, Vancouver, BC, Canada).

\section{Live cell calcium imaging}

Primary AF cells were passaged onto $14 \mathrm{~mm}$ glass bottom microwell dishes (MatTek, Fisher Scientific, NC9069930) at a density of $\sim 5,000$ cells $/ \mathrm{cm}^{2}$, allowed to adhere for $2 \mathrm{~h}$ and cultured in DMEM/F12 containing $10 \% \mathrm{FBS}$ and $1 \%$ penicillin/streptomycin for $24 \mathrm{~h}$. On the day of the experiment, cells were incubated for $40 \mathrm{~min}$ at $37^{\circ} \mathrm{C}, 5 \% \mathrm{CO}_{2}$ with $2.5 \mu \mathrm{m}$ calcium-sensitive Fura-2 (Fura-2, AM, Thermo Fisher Scientific, F1221) in culture medium. After loading, cells were rinsed once and medium was replaced with warm $\left(37^{\circ} \mathrm{C}\right) \mathrm{HEPES}$ buffer containing $135 \mathrm{mmol} / \mathrm{L} \mathrm{NaCl}, 5 \mathrm{mmol} / \mathrm{L} \mathrm{KCl}, 1 \mathrm{mmol} / \mathrm{L} \mathrm{MgCl}_{2}$, $1 \mathrm{mmol} / \mathrm{L} \mathrm{CaCl}_{2}, 10 \mathrm{mmol} / \mathrm{L} \mathrm{D}(+)$-glucose, $20 \mathrm{mmol} / \mathrm{L}$ HEPES (buffer adjusted to $290 \pm 5 \mathrm{mOsm} / \mathrm{L}$ and $\mathrm{pH}$ $7.30 \pm 0.02)$. Dishes were placed on a stage warmer $\left(35^{\circ} \mathrm{C}\right)$ mounted on a Nikon inverted microscope (Nikon Eclipse TE2000-U) and imaged using a Plan Fluor $40 \times / 1.3 \mathrm{NA}$ oil/water immersion objective. Cells were excited with alternating wavelengths of 345/380 nm using a DeltaRAM ${ }^{\mathrm{TM}} X$ Illuminator (Horiba Photon Technology International Inc., Birmingham, NJ, USA) and the emission was acquired using a bandpass filter $(510 \pm 20 \mathrm{~nm})$ (Kovac et al., 2008). Images were acquired every $5 \mathrm{~s}$ using a pco. edge 4.2 LTsCMOS camera (PCO AG, Kelheim, Germany) and EasyRatioPro 2.3 Software (Horiba Photon Technology International Inc.). For all calcium imaging experiments, the following protocol was used: 5 min incubation for baseline measurement, $10 \mathrm{~min}$ incubation following addition of either TRPV4 antagonist GSK2193874 (GSK219; $250 \mathrm{nmol} / \mathrm{L}$ ) or vehicle control $(0.1 \% \mathrm{v} / \mathrm{v}$ DMSO diluted in HEPES buffer), followed by image acquisition for $20 \mathrm{~min}$ after addition of the TRPV4 agonist GSK1016790A (GSK 101; $100 \mathrm{nmol} / \mathrm{L}$ ). Using this protocol, 420 images were acquired for each experiment. The ratiometric calcium measurements ( $345 / 380 \mathrm{~nm}$ ratio) were determined using a manually defined ROI corresponding to individual cells in the field of view (14-22 cells per experiment) and each experimental condition was repeated 3 times from different cell preparations established from different mice (3 biological replicates). In the vehicle + GSK101-treated group, the proportions of cells eliciting intracellular calcium response was quantified by categorising each cell $(n=67)$ into one of 3 groups according to changes in the $345 / 380 \mathrm{~nm}$ ratio upon TRPV4 activation: no 
Table 1. Sequences of the primers used in the real-time PCR analysis.

\begin{tabular}{|c|c|c|}
\hline Gene & Forward $\left(\mathbf{5}^{\prime} \rightarrow \mathbf{3}^{\prime}\right)$ & Reverse $\left(\mathbf{5}^{\prime} \rightarrow \mathbf{3}^{\prime}\right)$ \\
\hline Acan & CCTGCTACTTCATCGACCCC & AGATGCTGTTGACTCGAACCT \\
\hline Col1a1 & CTGGCGGTTCAGGTCCAAT & TCCAGGCAATCCAGGAGC \\
\hline Col2a1 & GCACATCTGGTTTGGAGAGACC & TAGCGGTGTTGGGAGCCA \\
\hline Prg 4 & GGGTGGAAAATACTTCCCGTC & CAGGACAGCACTCCATGTAGT \\
\hline Trpo 4 & TTCGTAGGGATCGTTGGTCCT & TACAGTGGGGCATCGTCCGT \\
\hline
\end{tabular}

response (ratio 0.76-0.92), oscillation (ratio fluctuating above and below 1.0), sustained (ratio above 1.0).

\section{Cytoskeleton staining}

Primary AF cells were seeded at a density of 48,000 cells $/ \mathrm{cm}^{2}$ onto a standard $35 \mathrm{~mm}$ dish and cultured for 2 d. Following expansion, AF cells were treated for $30 \mathrm{~min}$ with GSK 101 (10 nmol/L or $100 \mathrm{nmol} / \mathrm{L}$ ) in culture medium to activate TRPV4. AF cells treated for $30 \mathrm{~min}$ with vehicle $(0.1 \%$ DMSO v/v diluted in culture medium) served as a control. Following acute TRPV4 activation, cells were fixed with $4 \%$ paraformaldehyde for $10 \mathrm{~min}$, permeabilised with $0.1 \%$ Triton X-100 for $10 \mathrm{~min}$ at room temperature and blocked with BSA (in PBS) for 30 min. Alexa Fluor 488 Phalloidin (Life Technologies) was used to detect F-actin, according to manufacturer's protocol, and Hoeschst stain (Thermo Fisher) was used to visualise the nuclei. Images were acquired using a Leica DMI6000 inverted microscope and Leica Application Suite Software. For each of the 3 biological replicates, 3 non-overlapping ROIs were imaged for each treatment group.

To determine the role of ROCK signalling, AF cells were pre-treated with the pan ROCK inhibitor Y-27632 (10 $\mu \mathrm{m}$; STEMCELL Technologies) or vehicle (equal volume of sterile water) in culture medium for $24 \mathrm{~h}$ prior to $30 \mathrm{~min}$ incubation with $100 \mathrm{nmol} / \mathrm{L}$ GSK 101. Following acute exposure to TRPV4 agonist, cells were processed, stained for F-actin and imaged as described above.

\section{Mechanical stimulation}

The MechanoCulture B1 device (CellScale Biomaterials Testing, Waterloo, ON, Canada) was used to deliver bi-axial multi-directional CTS to AF cell cultures, as previously described (Kim et al., 2020). Primary AF cells were seeded at a density of 48,000 cells $/ \mathrm{cm}^{2}$ onto FBS-coated silicone membranes and cultured for $2 \mathrm{~d}$ in culture medium. AF cells were exposed to $10 \%$ CTS, at a sinusoidal frequency of $1.0 \mathrm{~Hz}$ for $30 \mathrm{~min}$ in the presence or absence of the TRPV4 antagonist GSK219 (250 nmol/L). To measure the direct effects of TRPV4 channel activation on AF cell gene expression, AF cells were treated with $100 \mathrm{nmol} / \mathrm{L}$ GSK101 for $30 \mathrm{~min}$ in the absence of CTS. AF cells cultured on FBS-coated silicone membranes treated with vehicle $(0.1 \%$ DMSO) in static culture served as timematched unloaded vehicle controls. After $30 \mathrm{~min}$ of treatment (CTS, CTS + GSK219 or GSK101 only), cells were incubated for an additional $6 \mathrm{~h}$ before harvesting for total RNA extraction. To limit the exposure of cells to the pharmacological TRPV4 modulators, following 30 min treatment, cells were rinsed, medium was replaced and cells were incubated for an additional $6 \mathrm{~h}$ before harvest.

\section{RNA extraction and gene expression analysis}

Total RNA was extracted from NP and AF tissues harvested at 2.5, 6, 9 and 12 months $(n=3)$ as well as CTS-treated AF cells $(n=3)$ using Trizol reagent (Life Technologies), according to the manufacturer's protocol. RNA was quantified using a NanoDrop 2000 spectrophotometer (Thermo Fisher Scientific). cDNA was synthesised from 150 ng of RNA using the Bio-Rad iScript cDNA synthesis kit (Bio-Rad). Gene expression was determined by SYBR-based real-time PCR using the Bio-Rad CFX384 thermocycler. PCR reactions were run in triplicate using $470 \mathrm{nmol} / \mathrm{L}$ forward and reverse primers (Table 1 ) and $2 \times$ SsoFast EvaGreen Supermix (Bio-Rad). The PCR program consisted of the following: initial 2 min enzyme activation at $95{ }^{\circ} \mathrm{C} ; 10 \mathrm{~s}$ denaturation at $95^{\circ} \mathrm{C}, 30 \mathrm{~s}$ annealing/elongation at $60^{\circ} \mathrm{C}$, for a total of 40 cycles. Trpv4 transcript levels in NP and AF tissues were quantified relative to a 6-point standard curve made from pooled cDNA generated from wild-type murine heart, brain, kidney and IVDs. For CTS experiments, gene expression was quantified using the $\Delta \Delta \mathrm{Ct}$ method, normalised to Hprt expression and expressed relative to time-matched unloaded controls.

\section{Statistical analyses}

Statistical analyses were performed using GraphPad Prism 8. qPCR analyses of IVD gene expression over time or in mechanically stimulated AF cells were assessed using two-way ANOVA with Tukey's multiple comparison test. qPCR analyses comparing GSK101-treated AF cells and vehicle control were assessed by two-tailed, unpaired $t$-test. $p<0.05$ was considered statistically significant. For timed mating experiments, 3-5 embryos derived from 2 different litters were used at each time point. For ageing studies, 3-4 mice for each time points were used. In parallel, AF and NP tissues isolated from 3 wild type mice were used for characterising Trpv 4 expression over time. All in vitro experiments had 3 independent cell preparations derived from different animals (3 biological replicates). 
a

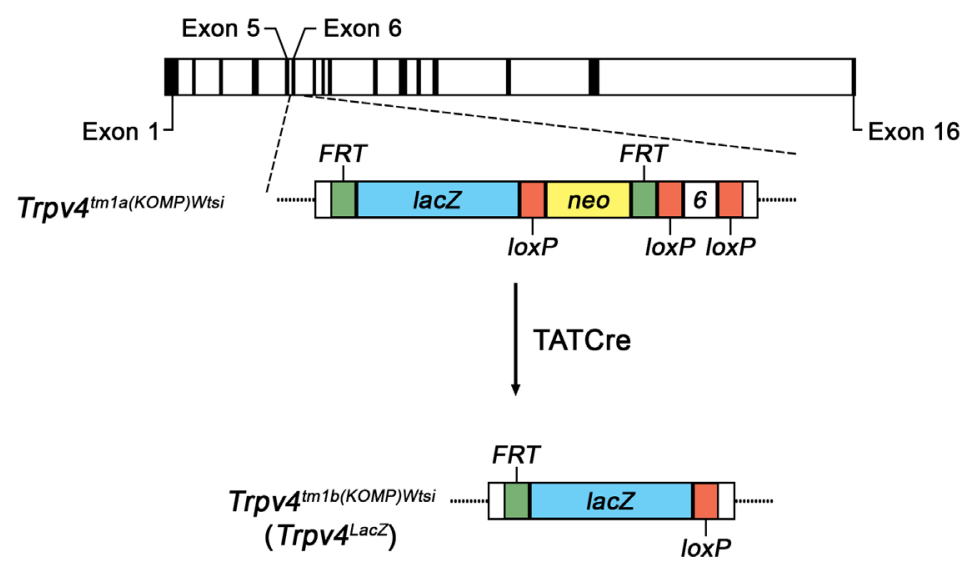

b

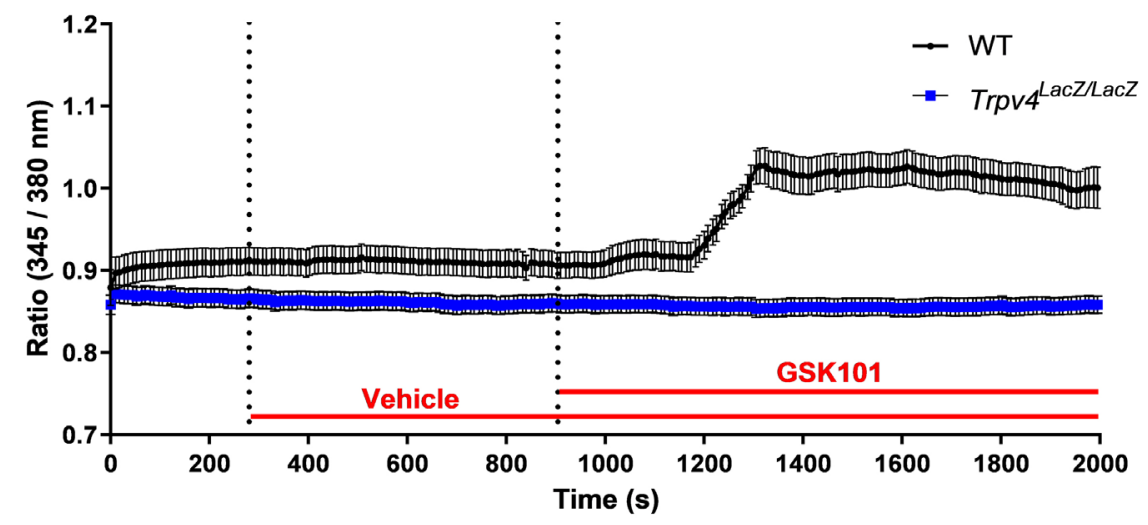

C

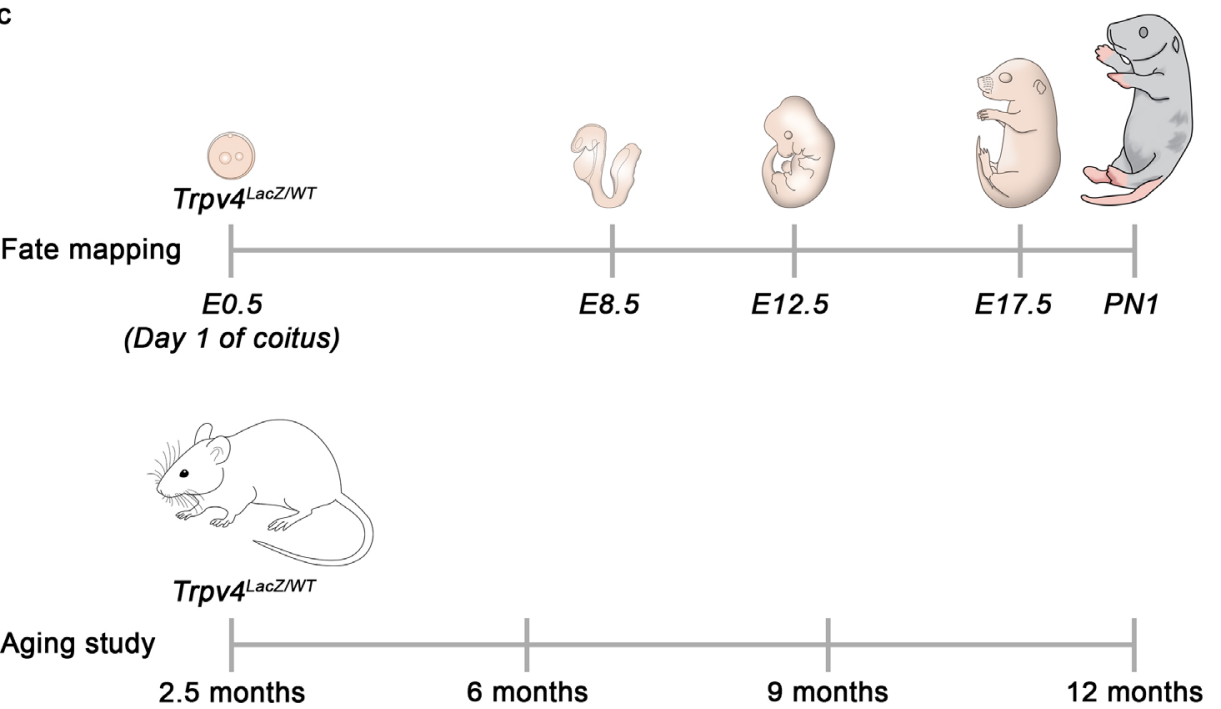

Fig. 1. Generation of Trpv $4^{t m 1 b}$ reporter mouse and schematic overview of experimental workflow. (a) EUCOMM "knock-out first" gene trap strategy used to generate the Trpv4 reporter mouse. The L1L2_Bact_P cassette was inserted upstream of the critical exon (exon 6) in the Trpv4 locus. The cassette included FRT site, lac $Z$ sequence and a loxP site. The first loxP site was followed by a neomycin-resistance gene, a second FRT site and a second loxP site. A third loxP site was inserted downstream of the targeted exon 6 . The resulting construct had exon 6 of Trpv 4 flanked by loxP sites (tm1a). The tm1a mice were Cre-excised to remove the neomycin-resistance cassette and exon 6 , to generate reporter mice $(\mathrm{tm} 1 \mathrm{~b})$, where the Trpv4 locus drove the expression of the LacZ gene (Trpv4 $4^{\text {LacZ/LacZ) }}$. (b) Calcium traces of AF cells isolated from 2.5 month old WT and Trpv $4^{\text {LacZ/LacZ }}$ mice treated with the TRPV4 agonist GSK101 (100 nmol/L). After incubation with Fura-2, AF cells were imaged during $5 \mathrm{~min}$ of calibration, $10 \mathrm{~min}$ following administration of vehicle $(0.1 \% \mathrm{v} / \mathrm{v}$ DMSO) and then 20 min following administration of GKS101 (100 nmol/L). Calcium response induced by GSK101, indicative of TRPV4 activation, was detected in WT AF cells, but was absent in Trpv4 $4^{\text {LacZ/LacZ }}$ AF cells ( $n=3$ per genotype). (c) Trpv $4^{\text {LacZ/WT }}$ embryos at E8.5, E12.5, E17.5 and PN1 were harvested for fate mapping experiments. Mice 2.5, 6, 9, 12 months old were used to characterise Trpv4 expression in the murine IVD over time. 


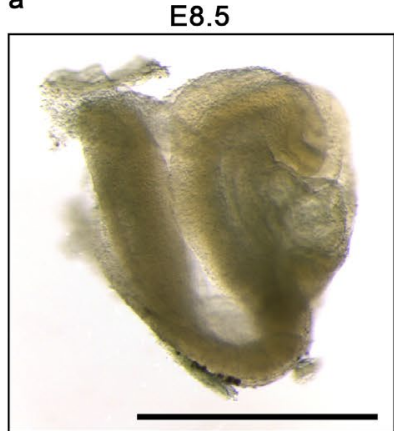

b

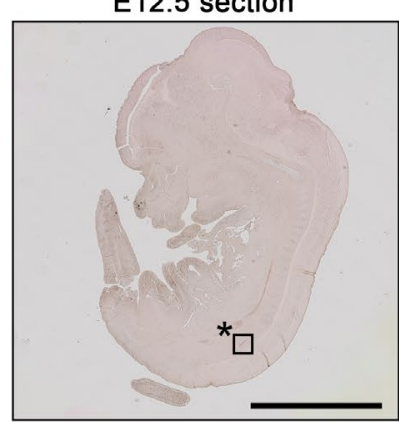

C

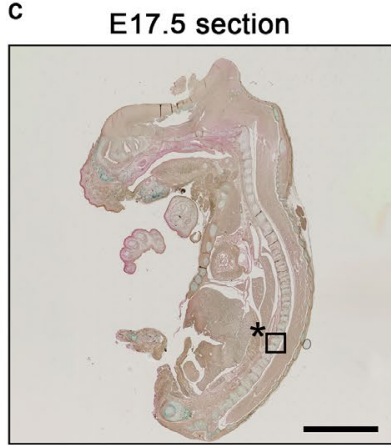

d

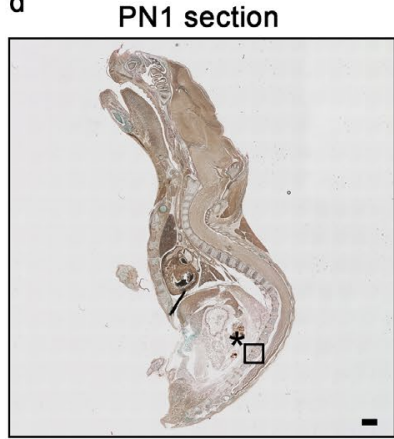

E12.5

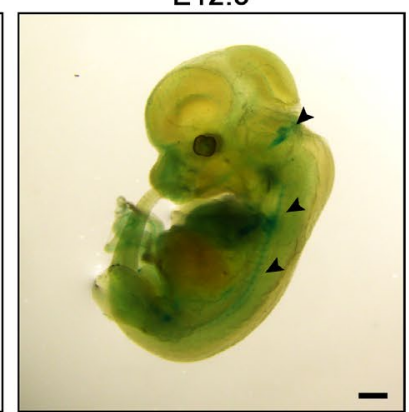

E12.5 notochord

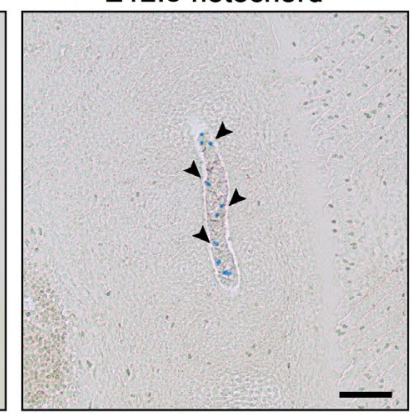

E17.5 lumbar

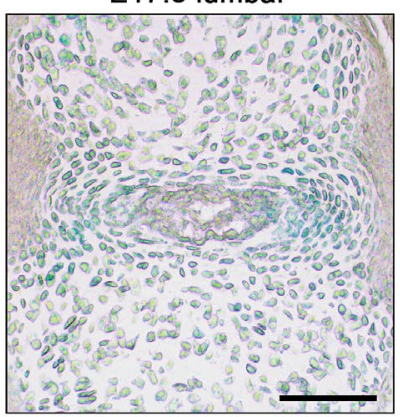

PN1 lumbar

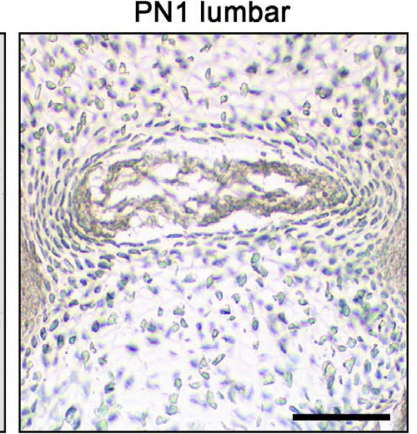

E17.5

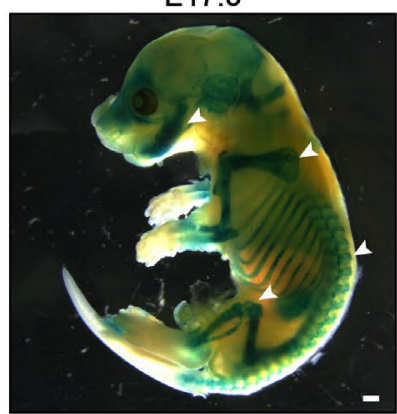

E12.5 brightfield

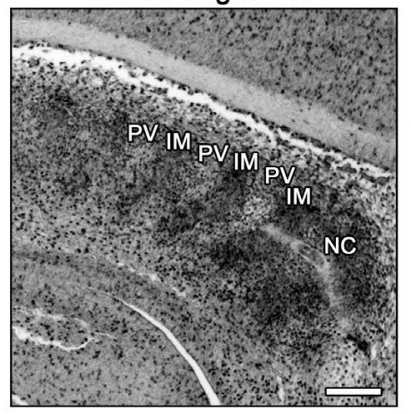

E17.5 brightfield

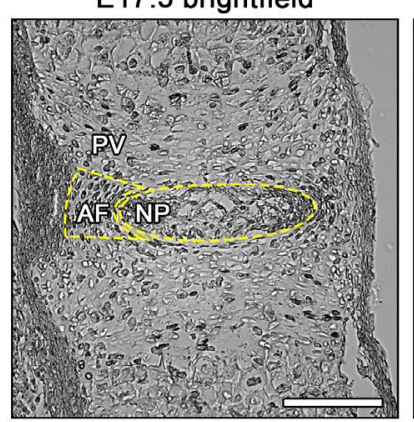

PN1 brightfield

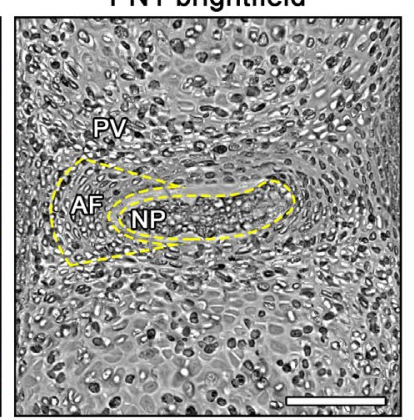

PN1

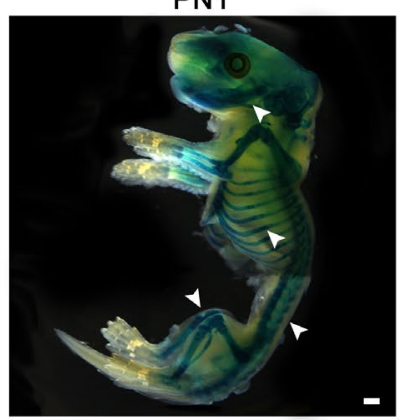

E12.5 beta-galactosidase

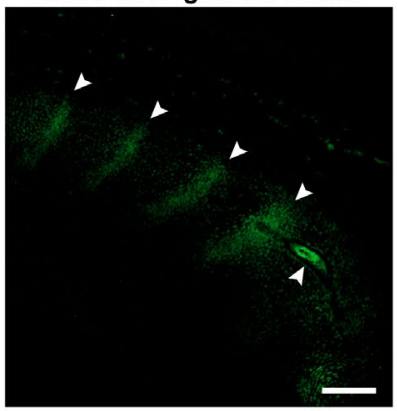

E17.5 beta-galactosidase

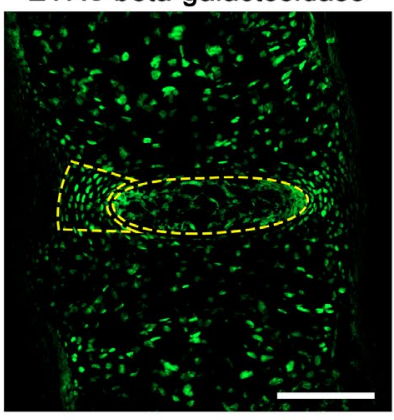

PN1 beta-galactosidase

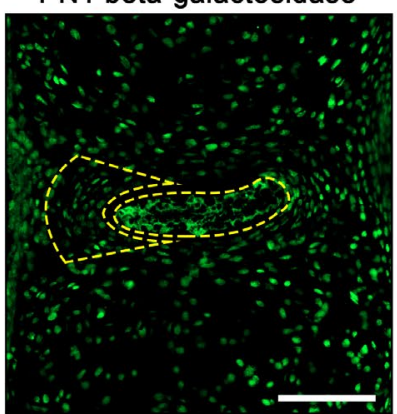

Fig. 2. Localisation of Trpv4-expressing cells during mouse spinal development. (a) Representative images of Trpv4 $4^{\text {LacZ/WT }}$ mice at E8.5, E12.5, E17.5 and PN1. Embryos were cleared and X-gal stain was used to detect $\beta$-galactosidase activity. Trpv4 expression, indicated by blue $\beta$-galactosidase staining (arrows), was not detected in embryos at E8.5, but was detected in the developing limb buds, structure of medulla oblongata and notochord at E12.5. At E17.5 and PN1, the cartilage primordium of mandible, limbs, ribs and spine were positive for $\beta$-galactosidase. (b) Midsagittal section of Trpv $4^{\text {LacZ/WT }}$ embryos at E12.5 either counterstained with eosin or assessed by immunofluorescence using $\beta$-galactosidase antibody $(1: 500)$. $\beta$-galactosidase activity was patchy in the notochord (asterisk) at E12.5; however, immunofluorescencebased detection showed localisation to the notochord (NC) as well as the intervertebral mesenchyme (IM), but not at the pre-vertebrae (PV) region of the developing spine. (c,d) $\beta$-galactosidase was detected in primitive AF, NP and pre-vertebrae (PV) at both E17.5 and PN1 using both staining methods. Scale bar: $1 \mathrm{~mm}, n=3-5$ embryos/time point derived from at least 2 different litters. 


\section{Results}

Loss of TRPV4 function in Trpv $4^{\mathrm{LacZ} / \mathrm{LacZ}}$ mice The EUCOMM gene trap strategy used to generate Trpv $4^{t m 1 b(K O M P) W t s i}$ reporter mice involved targeting the endogenous Trpv4 locus with a LacZ reporter (Fig. 1a). To validate this mouse model, the calcium response was examined in primary AF cells from mice homozygous for the transgene insertion (Trpv $4^{\text {LacZ }}$ ${ }^{L a c Z}$ ) treated with the TRPV4 agonist GSK101. Acute stimulation of AF cells with GSK101 (100 nmol/L) elicited a rise in intracellular calcium in WT AF cells, but not in Trpv $4^{\text {LacZ/LacZ }}$ AF cells, confirming the absence of functional TRPV4 channel in the homozygous reporter mouse (Fig. 1b). Previous studies reported that mice with global knockout of Trpv4 show accelerated osteoarthritis and increased bone mass due to impaired osteoclast activity (Clark et al., 2010; Masuyama et al., 2008). To avoid detrimental effects due to complete loss of TRPV4 function, all subsequent studies were conducted using Trpv $4^{\text {LacZ/WT }}$ reporter mice.

Trpv4 was expressed in the notochord and primitive AF

Using heterozygous reporter mice (Trpv $4^{\text {Laczl }}$ $\left.{ }^{W T}\right)$, Trpo4 expression was localised during IVD development. At E8.5, no $\beta$-galactosidase staining was detected in embryos, suggesting that Trpv4 is not expressed at early stages of notochord formation and elongation (Fig. 2a; E8.5). At E12.5, $\beta$-galactosidase expression indicative of Trpv4 expression, was detected in the developing limb buds, regions of alar plate of myelencephalon, primitive axial skeleton and notochord (Fig. 2a; E12.5). To better resolve $\beta$-galactosidase expression within the developing spine, stained embryos were sectioned for histological analysis. Consistent with the whole mount examination, patchy $\beta$-galactosidase staining was detected in the notochord at E12.5. In addition to the notochord, immunofluorescence staining for $\beta$-galactosidase demonstrated expression in regions of intervertebral mesenchyme, highlighting the metameric patterning between the developing IVD and prevertebral structure (Fig. 2b). At E17.5 and PN1, the cartilage primordium of mandible, limbs, ribs and spine showed $\beta$-galactosidase expression indicative of Trpv4 expression (Fig. 2a). At both E17.5 and PN1, $\beta$-galactosidase expression was detected in cells of NP and AF as well as the developing bone (Fig. 2c,d).

\section{Trpv4 expression in the IVD differed based on anatomical region, tissue type and age}

In skeletally mature mice, Trpo4 expression was examined in midsagittal sections from the thoracic, lumbar and caudal spine. At 2.5 months, $\beta$-galactosidase expression, indicative of Trpv4 expression, was detected in the lumbar spine in NP and IAF cells, using both $\beta$-galactosidase colourimetric detection and immunofluorescence staining (Fig. 3a,b). No staining was detected in the outer AF. In keeping with previous reports, staining was detected also in chondrocytes throughout the vertebral growth plates (Mangos et al., 2007; Muramatsu et al., 2007; Phan et al., 2009). Interestingly, $\beta$-galactosidase staining was more intense in the tail IVDs when compared to thoracic and lumbar ones. In addition, $\beta$-galactosidase staining decreased with age. At 6 months, less $\beta$-galactosidase staining was detected in the NP and IAF when compared to 2.5 months. $\beta$-galactosidase staining was further reduced at 9 months and by 12 months few cells were positive for $\beta$-galactosidase staining (Fig. 3b).

To further quantify age-related changes in Trpv4 expression, gene expression analysis was performed using NP and AF tissues isolated from lumbar and caudal IVDs of wild-type mice. Although no significant difference in Trpv4 expression was detected with age in the lumbar IVDs, a significant decrease in Trpv4 expression was detected with age in both the NP and AF of the caudal IVDs. In the lumbar IVDs, Trpv4 expression was more robust in the AF when compared to the NP, with significant differences detected in tissues isolated at 6 months (Fig. 3c).

\section{TRPV4 was functionally active in AF cells}

To correlate Trpv4 expression to functional channel activation, changes in intracellular calcium were measured in primary AF cells isolated from wild-type mice 2.5 months old. Treatment of AF cells with the TRPV4 agonist GSK1016790A (GSK101; $100 \mathrm{nmol} / \mathrm{L}$ ) elicited an increase in intracellular calcium (Fig. $4 a)$, confirming functional receptor expression. The GSK101-induced calcium response in AF cells was inhibited when cells were pre-treated with TRPV4 antagonist GSK2193874 (GSK219; 250 nmol/L; Fig. 4b). Interestingly, AF cells treated with GSK101 demonstrated heterogeneity in TRPV4-dependent calcium responses, with cells showing either sustained, oscillatory or no calcium responses (Fig. 4c). To quantify the proportion of cells exhibiting each of the distinct calcium responses, fluorescence was assessed in ROIs corresponding to individual cells and thresholds were set to represent each calcium response: no response (340/380 ratio: 0.76-0.92), oscillation (340/380 ratio: fluctuating above and below 1.0), sustained (340/380 ratio: above 1.0). When all cells were assessed over 3 biological replicates $(n=67), 27 \%$ showed no response, $54 \%$ showed an oscillation response and $19 \%$ showed a sustained response to TRPV4 agonism (Fig. 4 d).

TRPV4 activation was associated with cytoskeletal remodelling in AF cells

TRPV4-mediated calcium signalling regulates cytoskeletal rearrangement in other cell types, including chondrocytes and trabecular meshwork cells (Ryskamp et al., 2016; Trompeter et al., 2020). Moreover, in many cell types, including chondrocyte and cancer cells, ROCK signalling regulates 

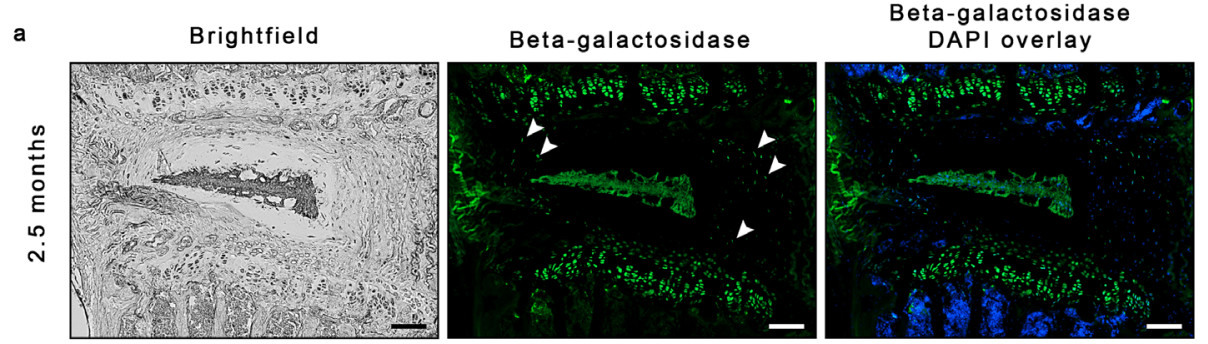

b
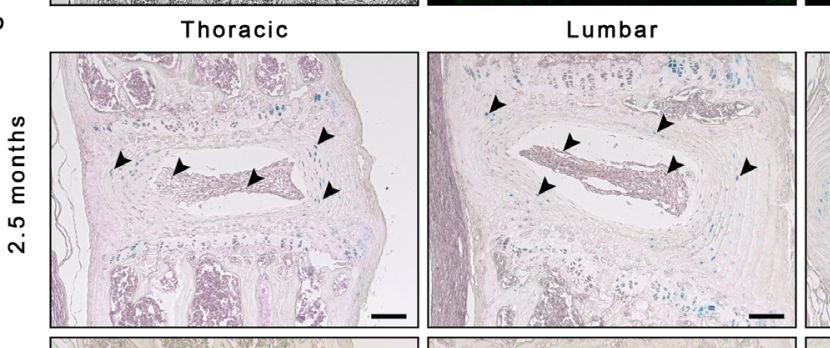

Tail tip

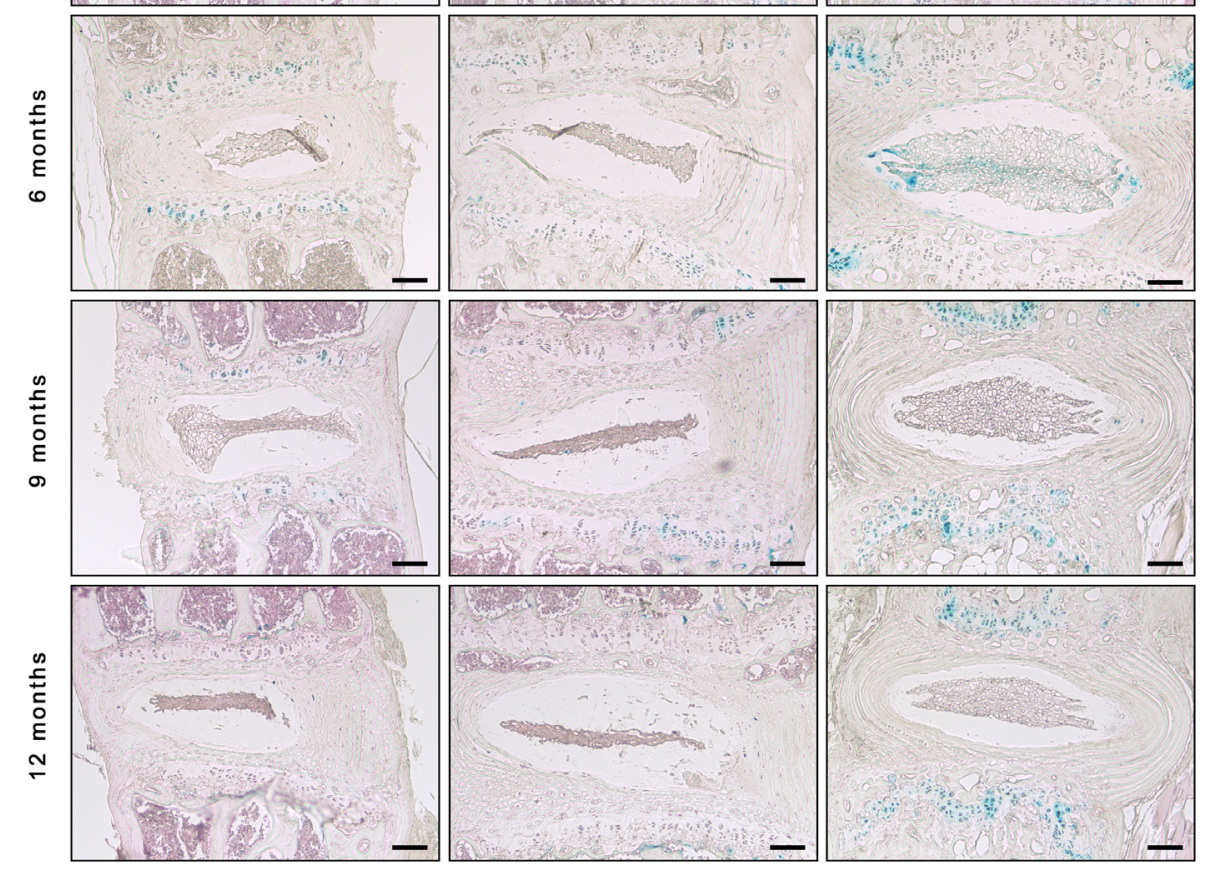

c
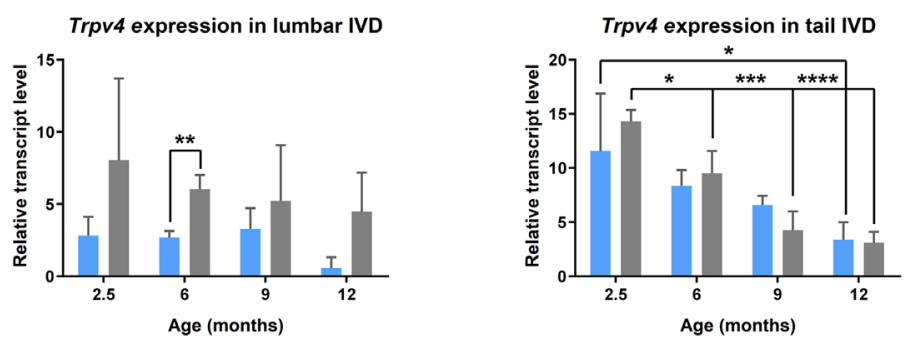

NP

Fig. 3. Characterisation of Trpv4 expression in the IVD over time. Midsagittal histological sections of different spinal regions (thoracic, lumbar or tail) from Trpv $4^{\operatorname{Lac} Z / W T}$ mice 2.5, 6, 9 and 12 months old. (a) Representative images of immunofluorescence-based detection of $\beta$-galactosidase in lumbar IVDs of 2.5 months old Trpv $4^{\text {LacZ/WT }}$ mice. NP and IAF cells were positive for $\beta$-galactosidase, indicative of Trpv4 expression (white arrows). (b) Representative midsagittal sections of IVDs of thoracic, lumbar or tail regions isolated from the Trpv $4^{\text {LacZ/WT }}$ reporter mice 2.5, 6, 9 and 12 months old. X-gal stain was used to detect $\beta$-galactosidase activity, indicative of Trpv4 expression. $\beta$-galactosidase staining was detected in NP and IAF (black arrows). Hypertrophic chondrocytes of the vertebral growth plate served as an internal positive control for each spine segments. Scale bar: $100 \mu \mathrm{m}, n=3-4$ mice/timepoint. (c) SYBR-based real-time qPCR quantifying the expression of Trpv4 in AF and NP tissues isolated from lumbar and tail IVDs at each time point. No significant changes in Trpv4 expression were detected in lumbar IVDs, except at 6 months when Trpv4 expression was increased in the AF, compared to the NP. A significant decrease in Trpv4 expression was detected with advancing age in both NP and AF tissues of tail IVDs. Data were analysed using twoway ANOVA with Tukey's multiple comparisons. ${ }^{*} p<0.05 ;{ }^{* *} p<0.01$; ${ }^{* * *} p<0.001$; ${ }^{* * *} p<0.0001$. Data presented in mean \pm SD. $n=3$. 
cytoskeletal remodelling in both physiological and pathological states (Amano et al., 2010; Bhadriraju et al., 2007; Woods et al., 2007). AF cells showed increased stress-fibre formation compared to untreated controls following acute treatment with increasing concentrations of the TRPV4 agonist GSK101 (Fig. 5a). Moreover, pre-treatment of AF cells with the ROCK inhibitor Y-27632 inhibited GSK101induced stress-fibre formation (Fig. 5b).

TRPV4 activation mediated the response of AF cells to cyclic tensile loading

The role of TRPV4 activation in mediating the response of AF cells to mechanical load was assessed.
Cells were exposed to $10 \%$ CTS at $1.0 \mathrm{~Hz}$ for $30 \mathrm{~min}$ in the presence or absence of the TRPV4 antagonist, GSK219. Cells were harvested $6 \mathrm{~h}$ post CTS and gene expression analysis was performed to quantify the expression of Acan, Col1a1, Col2a1 and Prg4. The expression of Col1a1 and Col2a1 by AF cells was not affected by CTS (Fig. 6). Interestingly, AF cells exposed to CTS in the presence of GSK219 showed significantly reduced Colla1 expression when compared to unloaded control and CTS-only group. In keeping with previous findings (Kim et al., 2020), CTS significantly increased Acan (1.5 \pm 0.1 -fold) and Prg4 $(1.7 \pm 0.2)$ expression compared to unloaded vehicle control, both inhibited by the presence of
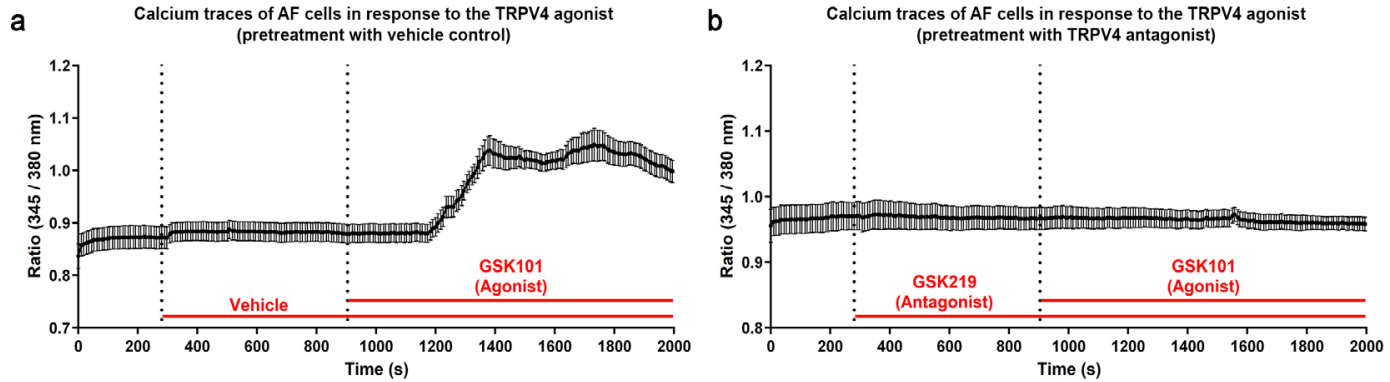

C
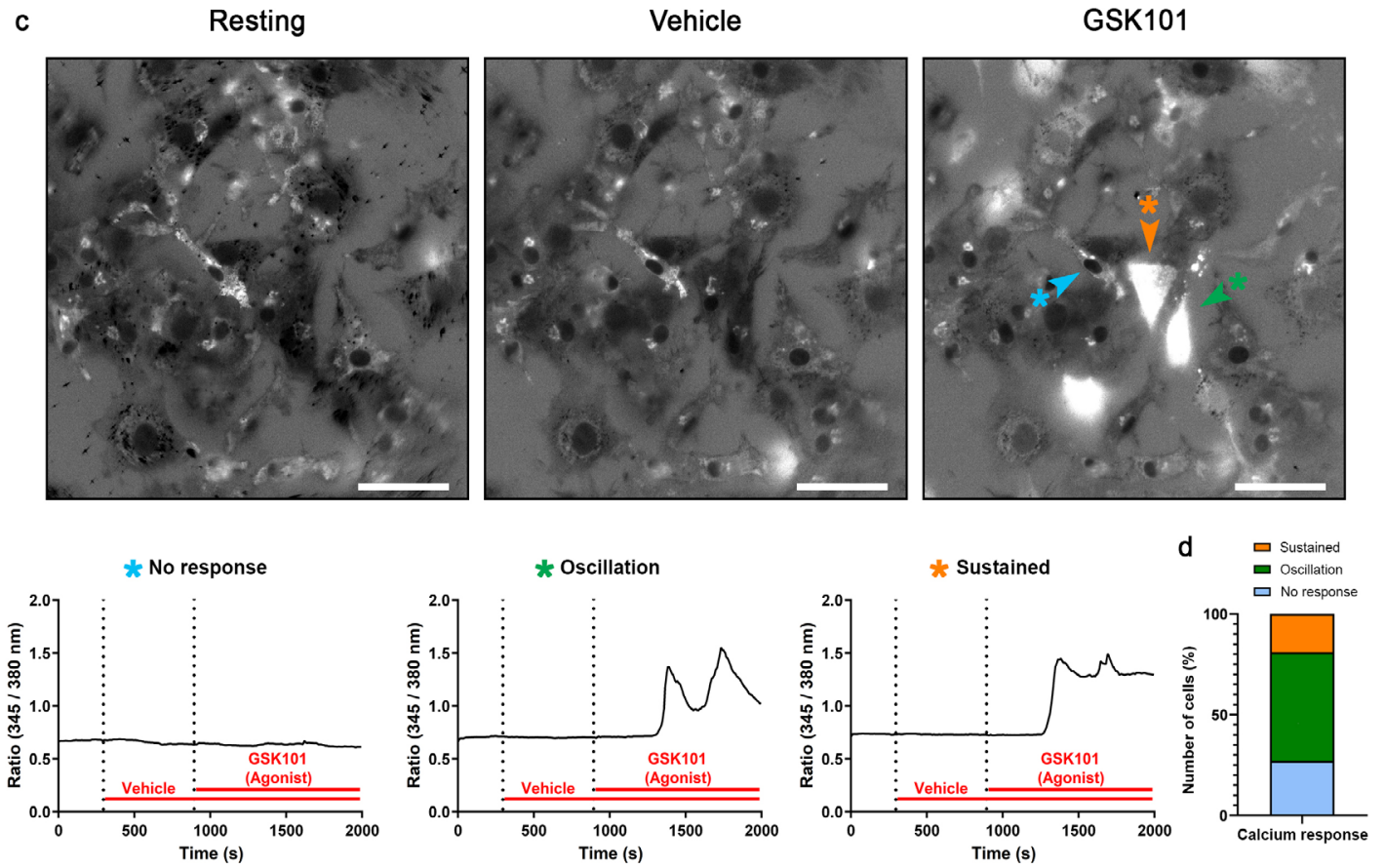

Fig. 4. TRPV4 activity in primary AF cells. (a) Representative calcium signalling traces in AF cells isolated from 2.5 months old WT mice in response to the TRPV4 agonist GSK101 $(100 \mathrm{nmol} / \mathrm{L})$, confirming the expression and functionality of TRPV4. Following incubation with Fura-2, AF cells were imaged for $5 \mathrm{~min}$ of calibration, $10 \mathrm{~min}$ following administration of vehicle ( $0.1 \% \mathrm{v} / \mathrm{v}$ DMSO) and $20 \mathrm{~min}$ following administration of GKS101 (100 nmol/L). Graph represents the average calcium response of all cells in the field of view from 3 biological replicates $(n=67)$. (b) The calcium response induced by GSK101 was inhibited by pre-treatment of AF cells with the TRPV4 antagonist GSK219 $(250 \mathrm{nmol} / \mathrm{L})$. (c) Representative images of fluorescence signals at distinct stages of treatment. TRPV4 activation by GSK101 yielded one of three calcium responses in AF cells: sustained, oscillation and no response. (d) Stacked histogram showing the proportions of AF cells showing the distinct calcium responses following TRPV4 activation. Cells were categorised based on their response to the TRPV4 agonist as defined by their specific fluorescence ratio: $27 \%$ of cells showed no response (340/380 ratio 0.76-0.92), $54 \%$ of cells showed oscillation (340/380 ratio fluctuating above and below 1.0) and $19 \%$ of cells showed a sustained response (340/380 ratio above 1.0). Scale bar: $100 \mu \mathrm{m} ; n=67$ cells assessed from a total of 3 independent cell preparations. 
GSK219 during mechanical stimulation (Fig. 6). These findings suggested that TRPV4 is an important sensor of CTS in AF cells.

To measure the direct effects of TRPV4 activation on AF cell gene expression, cells were exposed to the TRPV4 agonist GSK101 using a protocol designed to mimic that used for CTS. AF cells were treated with GSK101 for 30 min in static culture, rinsed and incubated with fresh medium for further $6 \mathrm{~h}$ prior to harvest. In keeping with the effects of CTS, treatment of AF cells with GSK101 induced a significant increase in Acan (1.8 \pm 0.3-fold) and Prg4 (2.1 \pm 0.1 -fold) expression when compared to vehicle control (Fig. 7). TRPV4 agonism did not alter Col1a1 or Col2a1 expression.

\section{Discussion}

The IVD represents a mechanically dynamic environment, in which cells receive mechanical cues from their surrounding microenvironment and transduce this information into intracellular biochemical signals that regulate cellular processes. Although there is growing evidence for the effects of different types of mechanical stimulation on IVD biology, information on mechano-receptors that sense and transduce the mechanical signals remains limited. The present study used a novel transgenic reporter mouse model to characterise the spatiotemporal pattern of TRPV4 expression in the murine IVD during development and in skeletally mature
IVD tissues. The study demonstrated that TRPV4 activation in AF cells elicited intracellular calcium response and regulated cytoskeleton remodelling. Using a mechanically dynamic bioreactor system and pharmacological modulation of TRPV4 activation, TRPV4-dependent response of AF cells to CTS was shown to alter ECM gene expression and cytoskeletal rearrangement. These data establish TRPV4 as an important mechano-sensor regulating IVD mechanobiology.

These findings in mice were consistent with previous studies describing Trpv4 expression during zebrafish embryogenesis (Mangos et al., 2007). In zebrafish, Trpv4 is first detected during notochord elongation and subsequently in other chondrogenic tissues in later developmental stages. Similarly, in the present reporter mouse model, Trpv 4 expression was detected in the notochord as well as the condensed segments of intervertebral mesenchyme, highlighting the metameric patterning of the spine at E12.5. Anatomically, the notochord is a continuous rod-like structure that creates the primitive axis of the embryo. Functionally, the notochord provides both mechanical and morphogenic signals to the developing embryo. During development, elongation of the notochord is thought to happen through two complementary mechanisms: i) convergent extension guided along the tension generated by the expanding amniotic cavity along the anterior/posterior axis (Imuta et al., 2014; Koyama and Fujimori, 2020; Wallingford et al., 2002); ii) vacuole expansion within notochord cells distributed along the embryonic axis by the rigid a

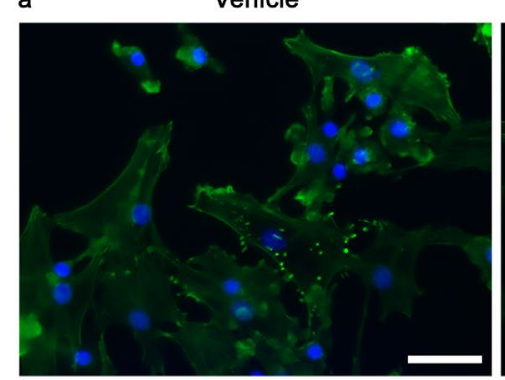

b

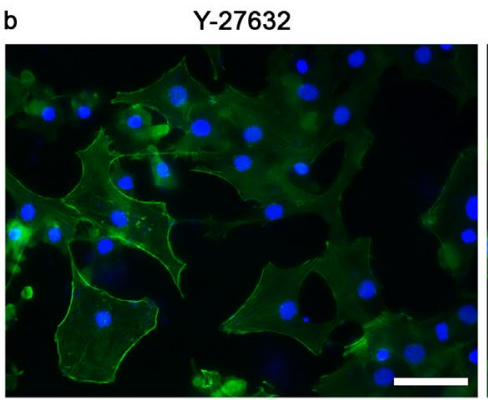

GSK101 (10 nmol/L)

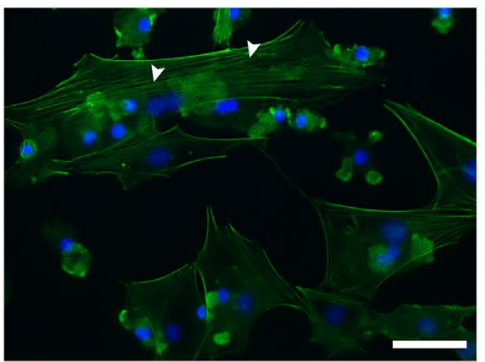

Vehicle + GKS101 (100 nmol/L)

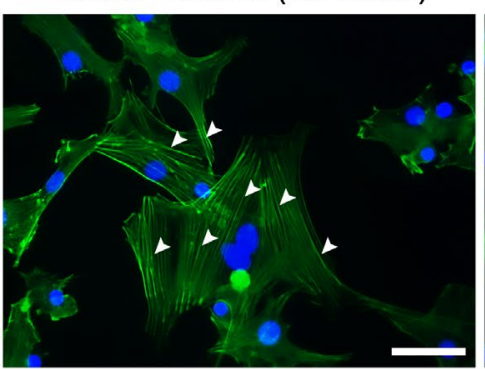

GSK101 (100 nmol/L)

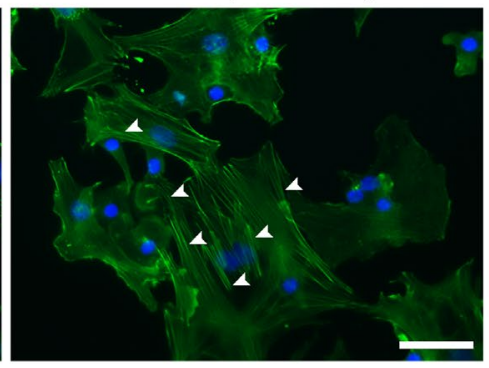

Y-27632 + GSK101 (100 nmol/L)

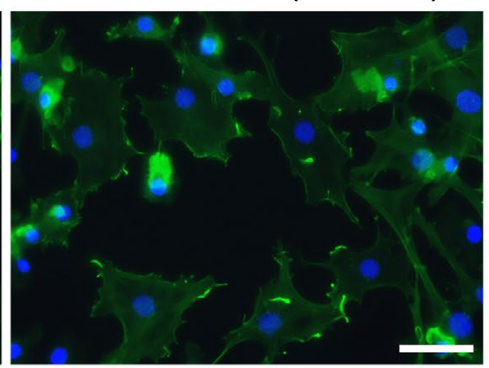

Fig. 5. Effect of TRPV4 activation on cytoskeleton remodelling in AF cells. (a) AF cells were incubated with increasing concentrations of GSK101 for $30 \mathrm{~min}$, fixed and stained with Alexa 488 Phalloidin to visualise the actin cytoskeleton. Increased stress-fibre formation (white arrows) was detected with increasing concentrations of GSK101, suggesting the cytoskeletal network of the AF cells was changing following acute activation of TRPV4. (b) GSK101-induced stress-fibre formation was inhibited when cells were pre-treated with Y-27632 (ROCK inhibitor). Scale bar: $50 \mu \mathrm{m} ; n=3$ independent cell preparations derived from 3 different 2.5 months old mice. 
ECM of the notochordal sheath restricting bilateral cell volume expansion (Adams and Koehu, 1990; Ellis et al., 2013b; Jurand, 1974; Koehl et al., 2000; Paavola et al., 1980). TRPV4 has been shown to regulate cell volume during cellular osmoregulation (Becker et al., 2005; Liedtke and Friedman, 2003) and respond to both compressive and tensile load in multiple cell types (Du et al., 2020; Mochizuki et al., 2009; O'Conor et al., 2014; Pairet et al., 2018; Thodeti et al., 2009a). Importantly, TRPV4 expression is detected in the notochord of zebrafish at the time of vacuole inflation (Ellis et al., 2013a; Mangos et al., 2007). As such, Trpv4 expression in the notochord may mediate notochord development as a mechano-receptor and osmosensor, transducing the directionality of mechanical signals and regulating notochord cell volume expansion, respectively. Furthermore, intracellular calcium signalling regulates embryogenesis in other animal models. Previous studies investigating calcium signalling in the developing zebrafish showed large intracellular calcium transients in the trunk region during early and late segmentation (Tsuruwaka et al., 2017). Additionally, intracellular calcium signals regulate cell proliferation, migration and shape during zebrafish embryogenesis (Blaser et al., 2006;
Bonneau et al., 2011; Reinhard et al., 1995; Sahu et al., 2017; Webb and Miller, 2000). Trpv4 expression detected in the condensed mesenchymal segments at E12.5 in the mouse suggested that TRPV4-mediated calcium signalling may contribute to the regulation of cell proliferation and migration required for metameric patterning along the longitudinal axis.

In skeletally mature mice, Trpo 4 expression was detected in NP and IAF cells, with differential expression detected based on anatomical region and age. The differences in Trpv4 expression in spinal regions may result from differences in mechanical load experienced in these tissues. Kim et al. (2020) showed that Trpou expression is upregulated in AF cells following mechanical stimulation. Accordingly, increased Trpv4 expression detected in lumbar and tail IVDs, compared to thoracic IVDs, may be due to more mechanical load experienced at these sites. Furthermore, during development, notochord segmentation and mesenchymal condensation initiated at E13.5 progresses in the rostral-to-caudal direction (Jurand, 1974). As such, it is tempting to speculate that as a result of the temporal differences in IVD formation across the spine, caudal IVDs may be somewhat less mature when compared to
Acan

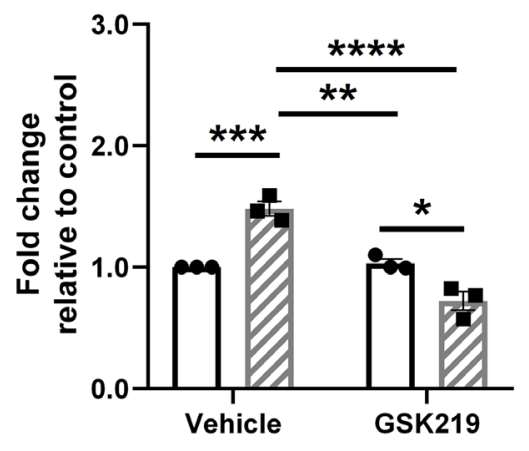

Col2a1

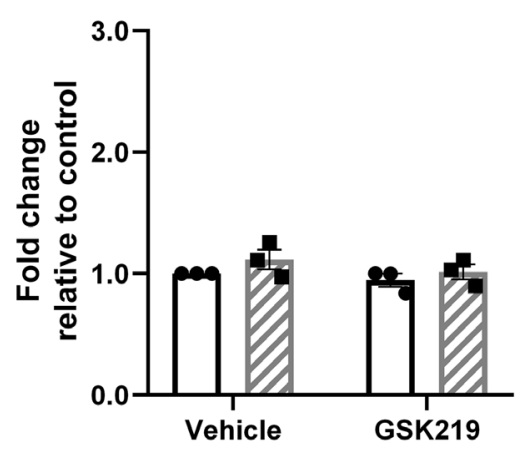

Col1a1
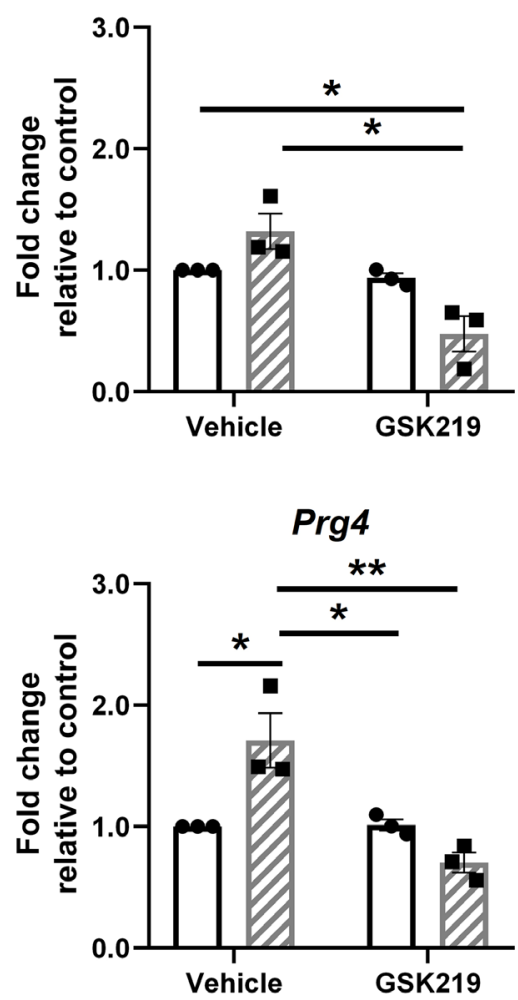

Fig. 6. TRPV4-dependent gene expression in mechanically stimulated AF cells. AF cells were subjected to $10 \%$ CTS at $1.0 \mathrm{~Hz}$ for $30 \mathrm{~min}$ in the presence or absence of TRPV4-specific antagonist, GSK219. $6 \mathrm{~h}$ post CTS, cells were harvested for gene expression analysis to quantify the expression of candidate ECM genes. CTS induced an upregulation of Acan and Prg4 expression, which was blocked by treatment with the TRPV4 antagonist GSK219. Relative gene expression was calculated using the $\triangle \mathrm{Ct}$ method, normalised to the housekeeping gene Hprt and expressed relative to time-matched unloaded vehicle control. Data presented as mean \pm SEM; $n=3$ cell preparations. Data were analysed using two-way ANOVA with Tukey's multiple comparisons. ${ }^{*} p<0.05 ;{ }^{* *} p<0.01 ;{ }^{* * *} p<0.001 ;{ }^{* * *} p<0.0001$. 
those in the lumbar or thoracic regions and, thus, show more robust expression of Trpv4 at time points associated with skeletal maturity. Moreover, the present study demonstrated decreased Trpv4 expression with increasing age. Tissue osmolarity and $\mathrm{pH}$ within the IVD decrease as aggrecan and other glycosaminoglycans are degraded with age or degeneration. Walter et al. (2016), investigating the role of TRPV4 in human IVDs, reported that culture of IVD explants in hypotonic conditions, thereby increasing the osmotic pressure, leads to increased TRPV4 protein expression. Notably, this study used a mechanically dynamic organ culture system delivering cyclic compression to IVD explants (0.0$0.8 \mathrm{MPa}$ at $0.1 \mathrm{~Hz}$ for $8 \mathrm{~h}$; $0.2 \mathrm{MPa}$ for $16 \mathrm{~h}$ ), which may also influence TRPV4 expression. In keeping with these studies, the decrease observed in Trpv4 expression with increasing age may be due to ageassociated changes in tissue osmolarity. The findings suggest cell type, anatomical region and age as factors that regulate Trpv4 expression in the murine IVD.

The present study showed that pharmacological activation of TRPV4 elicited one of three calcium responses in AF cells: sustained, oscillation or no response. This finding may relate to the heterogeneity of the primary cell culture system used, which contained cells of both inner and outer AF from IVDs of all anatomical regions. The cells that did not respond to TRPV4 agonism may be outer AF cells, in which Trpv4 expression was not detected. Results were consistent with previous findings
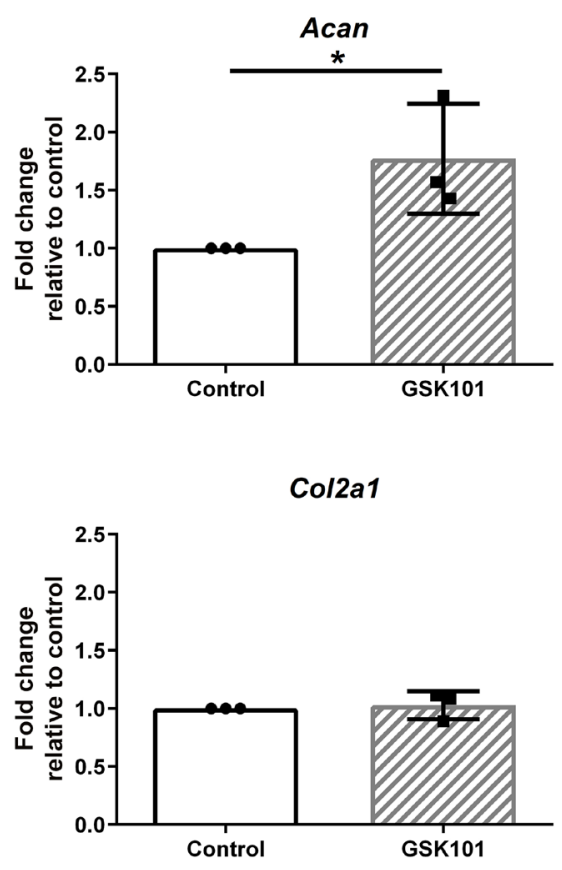

reporting sustained intracellular calcium response in AF and NP tissues upon direct activation of TRPV4 ion channel (Walter et al., 2016). Interestingly, intracellular calcium oscillation was observed in the present study. Calcium oscillation following TRPV4 activation drives matrix production in chondrocytes and regulates cell matrix adhesion and alignment in mesenchymal stem cells (Gilchrist et al., 2019; O'Conor et al., 2014). The presence of both sustained and oscillatory calcium response in the cell culture system may be due to agonist concentration and differences in receptor density on cell subpopulations. Previous studies of receptor activation in glial cells concluded that low agonist concentration elicits calcium oscillation, while high concentration leads to sustained responses (Kawano et al., 2002; Verkhratsky et al., 1998). In mesenchymal stem cells, TRPV4 activation with low agonist (GSK101) concentration (1 or $10 \mathrm{nmol} / \mathrm{L}$ ) leads to short oscillatory calcium transients, while high agonist concentration $(100 \mathrm{nmol} / \mathrm{L})$ induces sustained calcium response (Gilchrist et al., 2019). Furthermore, studies investigating the relationship between intracellular calcium and receptor density showed that changes in receptor density influence intracellular calcium response following receptor activation (Dickson et al., 2013; Ochsenbein et al., 1999). Given the differences between cells of the inner and outer AF in terms of ECM components, cell shape and mechanical environment (Fearing et al., 2018), it is possible that differential expression of TRPV4 in these cells may
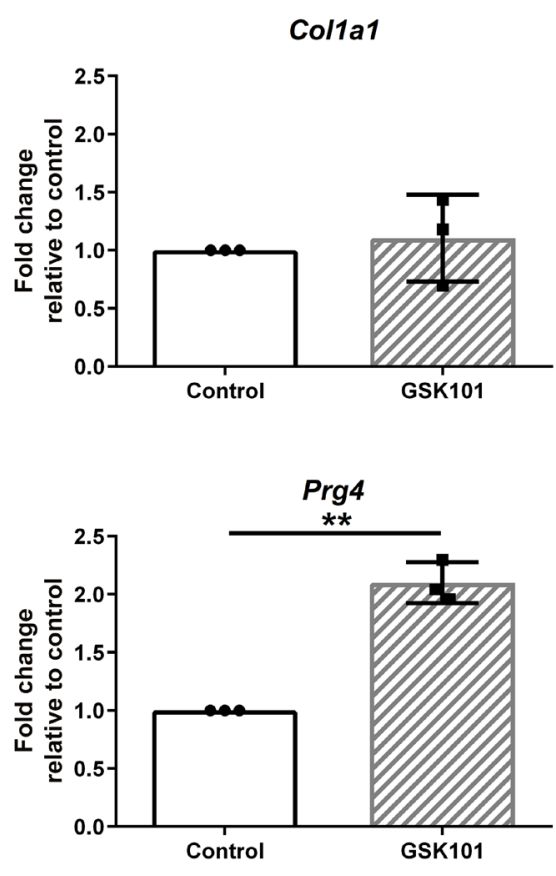

Fig. 7. TRPV4-mediated changes in AF cell gene expression. Primary AF cells were treated with the TRPV4 agonist GSK101 (100 nmol/L) for $30 \mathrm{~min}$ and, after $6 \mathrm{~h}$, cells were harvested for gene expression analysis to quantify the expression of candidate ECM genes. Treatment of AF cells with the TRPV4 agonist induced an upregulation in Acan and Prg4 expression. Relative gene expression was calculated using the $\triangle \mathrm{Ct}$ method, normalised to the housekeeping gene Hprt and expressed relative to time-matched vehicle control. Data presented as mean \pm SEM; $n=3$ cell preparations. Data were analysed using unpaired $t$-tests ${ }^{*} p<0.05 ;{ }^{* *} p<0.01$. 
account for the different cellular responses detected. Similarly, differences in TRPV4 expression in AF cells based on the anatomical location from which the IVDs were isolated may contribute to cell heterogeneity in the described model and influence the cellular responses detected.

One of the earliest cellular adaptations to mechanical stimulation is the formation of stress fibres (Hayakawa et al., 2001; Yavropoulou and Yovos, 2016; Ziegler et al., 2012). TRPV4-mediated calcium signalling regulates cytoskeletal rearrangement in several cell types, including chondrocytes and trabecular meshwork cells (Ryskamp et al., 2016; Trompeter et al., 2020). In primary AF cells, pharmacological activation of TRPV4 increased stressfibre formation, which was blocked by Rho/ROCK inhibition. In many cell types, including chondrocyte and cancer cells, Rho/ROCK signalling regulates cytoskeletal remodelling in both physiological and pathological states (Amano et al., 2010; Bhadriraju et al., 2007; Woods et al., 2007). The crosstalk between TRPV4 and ROCK has been studied in endothelial cells. In normal endothelial cells, TRPV4 senses mechanical force and induces RhoA/ROCK activation necessary for migration, stiffening and contraction (Liu et al., 2018). However, in a pathological state, Rho/ ROCK activation and cell stiffening cause decreased TRPV4 expression and pharmacological activation of TRPV4 supresses Rho/ROCK-mediated signalling (Xiao et al., 2016), suggesting that Rho/ROCK can act both as an effector and target of TRPV4. Similarly, the present study findings suggested the involvement of both TRPV4 and Rho/ROCK signalling in cytoskeleton remodelling and AF cell mechanotransduction. Moreover, in bovine endothelial cells, mechanical activation of TRPV4 induces phosphatidyl inositol-3-kinase/protein kinase B activation, which in turn, activates $\beta 1$ integrin, leading to cytoskeletal rearrangement (Thodeti et al., 2009b). Interestingly, in human endothelial cells, shear-stress-induced $\alpha 5 \beta 1$ integrin activation is necessary for the trafficking of TRPV4 channels to the cell membrane (Baratchi et al., 2017). Based on these findings, future studies should investigate the involvement of TRPV4-integrin-Rho/ ROCK crosstalk in AF mechano-transduction.

In other musculoskeletal cell types, intracellular calcium signalling is believed to be one of the earliest mechano-response events (Godin et al., 2007; Han et al., 2012; Morrell et al., 2018; Raizman et al., 2010). In chondrocytes, TRPV4 mediates the mechano-response, including gene expression and proteoglycan synthesis (O'Conor et al., 2014). Using a previously characterised culture system, the role of TRPV4 was assessed in the response of AF cells to cyclic tensile loading. TRPV4 activation was both necessary and sufficient for induction of Acan and Prg4 expression in response to CTS. Given the regional variance in type I and type II collagen expression in AF tissues (Bruehlmann et al., 2002; Iu et al., 2014) and the findings of Trpv4 expression in the IAF, the involvement of TRPV4-mediated signalling in regulating Col1a1 and Col2a1 was assessed. Although TRPV4 activation did not alter Col1a1 or Col2a1 expression, treatment of AF cells with the TRPV4 antagonist significantly reduced Col1a1 expression in the presence of CTS, suggesting a potential interplay between TRPV4-mediated signals and type I collagen regulation. It is important to acknowledge that the present study findings were limited to the characterisation of the response of AF cells to acute TRPV4 activation and future studies would be required to assess the effects of gain or loss of function of TRPV4 in regulating ECM gene expression in the IVD. Previous studies investigating the effects of both extracellular osmolarity and mechanical stimulation showed that in human AF cells, Col1a1 expression decreases with increasing osmolarity, while Acan and Col2a1 expression increases (Wuertz et al., 2007a). These studies showed also that mechanical stimulation to AF cells inhibits osmotically induced changes in Col1a1, Col2a1 and Acan expression, with the exception of increased Acan expression in a hypertonic environment (Wuertz et al., 2007a). Given that TRPV4 is a well-established osmosensor, future studies should investigate the role of TRPV4 in regulating mechano-response of AF cells in varying osmotic conditions.

\section{Conclusions}

The study findings showed that Trpv4 was first expressed in primitive IVD structures during development and persisted in cells of the mature NP and IAF. Specifically, in AF cells, TRPV4 activation was shown to be a key mechanism of mechanical signal transduction. In addition to previous evidence for TRPV4 being an osmosensor in the IVD, data highlighted TRPV4 as a mechano-receptor regulating cytoskeletal architecture and ECM gene expression. These findings highlighted the role of ion channel receptors in modulating cellular function through intracellular calcium transients. Understanding the mechanism of mechano-reception and mechanotransduction in IVD cells will help delineate cell-type specific mediators of mechano-response that regulate IVD health and degeneration.

\section{Acknowledgements}

M.K.M.K. was supported in part by the CONNECT! NSERC CREATE Training Program. This work was supported by the Natural Sciences and Engineering Research Council of Canada and the Bone and Joint Institute at the University of Western Ontario. C.A.S. was supported by a Career Development Award from the Arthritis Society and Early Researcher Award from the Ontario Ministry of Research and Innovation. 


\section{References}

Adams DS, Koehu MAR (1990) The mechanics of notochord elongation, straightening and stiffening in the embryo of Xenopus laevis. Development 110: 115-130.

Adams MA, Mcnally S, Dolan P, Mcnally DS (1996) "Stress" distributions inside intervertebral discs the effects of age and degeneration. J Bone Jt Surg Br 78: 965-972.

Amano M, Nakayama M, Kaibuchi K (2010) Rhokinase/ROCK: a key regulator of the cytoskeleton and cell polarity. 67: 545-554.

Arnbak B, Jensen TS, Egund N, Zejden A, HørslevPetersen K, Manniche C, Jurik AG (2016) Prevalence of degenerative and spondyloarthritis-related magnetic resonance imaging findings in the spine and sacroiliac joints in patients with persistent low back pain. Eur Radiol 26: 1191-1203.

Baratchi S, Knoerzer M, Khoshmanesh K, Mitchell A, McIntyre P (2017) Shear stress regulates TRPV4 channel clustering and translocation from adherens junctions to the basal membrane. Sci Rep 7: 15942. DOI: 10.1038/s41598-017-16276-7.

Becker D, Blase C, Bereiter-Hahn J, Jendrach M (2005) TRPV4 exhibits a functional role in cell-volume regulation. J Cell Sci 118: 2435-2440.

Bhadriraju K, Yang M, Ruiz SA, Pirone D, Tan J, Chen CS (2007) Activation of ROCK by RhoA is regulated by cell adhesion, shape, and cytoskeletal tension. Exp Cell Res 313: 3616-3623.

Blaser H, Reichman-Fried M, Castanon I, Dumstrei K, Marlow FLL, Kawakami K, Solnica-Krezel L, Heisenberg CP, Raz E (2006) Migration of zebrafish primordial germ cells: a role for myosin contraction and cytoplasmic flow. Dev Cell 11: 613-627.

Bonneau B, Popgeorgiev N, Prudent J, Gillet G (2011) Cytoskeleton dynamics in early zebrafish development. Bioarchitecture 1: 216-220.

Bruehlmann SB, Rattner JB, Matyas JR, Duncan NA (2002) Regional variations in the cellular matrix of the annulus fibrosus of the intervertebral disc. J Anat 201: 159-171.

Chan SCW, Ferguson SJ, Gantenbein-Ritter B (2011) The effects of dynamic loading on the intervertebral disc. Eur Spine J 20: 1796. DOI: 10.1007/ s00586-011-1827-1.

Clark AL, Votta BJ, Kumar S, Liedtke W, Guilak F (2010) Chondroprotective role of the osmotically sensitive ion channel transient receptor potential vanilloid 4: Age- and sex-dependent progression of osteoarthritis in Trpv4-deficient mice. Arthritis Rheum 62: 2973-2983.

Dickson EJ, Falkenburger BH, Hille B (2013) Quantitative properties and receptor reserve of the IP3 and calcium branch of Gq-coupled receptor signaling. J Gen Physiol 141: 521-535.

Du G, Li L, Zhang X, Liu J, Hao J, Zhu J, Wu H, Chen W, Zhang Q (2020) Roles of TRPV4 and piezo channels in stretch-evoked Ca 21 response in chondrocytes. Exp Biol Med 245: 180-189.
Ellis K, Bagwell J, Bagnat M (2013a) Notochord vacuoles are lysosome-related organelles that function in axis and spine morphogenesis. J Cell Biol 200: 667-679.

Ellis K, Hoffman BD, Bagnat M (2013b) The vacuole within. Bioarchitecture 3: 64-68.

Fearing BV, Hernandez PA, Setton LA, Chahine NO (2018) Mechanotransduction and cell biomechanics of the intervertebral disc. JOR Spine 1: e1026. DOI: 10.1002/jsp2.1026.

Gawri R, Moir J, Ouellet J, Beckman L, Steffen T, Roughley P, Haglund L (2014a) Physiological loading can restore the proteoglycan content in a model of early IVD degeneration. PLoS One 9: e101233. DOI: 10.1371/journal.pone.0101233.

Gawri R, Rosenzweig DH, Krock E, Ouellet JA, Stone LS, Quinn TM, Haglund L (2014b) High mechanical strain of primary intervertebral disc cells promotes secretion of inflammatory factors associated with disc degeneration and pain. Arthritis Res Ther 16: R21. DOI: 10.1186/ar4449.

Gilbert HTJ, Nagra NS, Freemont AJ, MillwardSadler SJ, Hoyland JA (2013) Integrin-dependent mechanotransduction in mechanically stimulated human annulus fibrosus cells: evidence for an alternative mechanotransduction pathway operating with degeneration. PLoS One 8: e72994. DOI: 10.1371/ journal.pone.0072994.

Gilchrist CL, Leddy HA, Kaye L, Case ND, Rothenberg KE, Little D, Liedtke W, Hoffman BD, Guilak F (2019) TRPV4-mediated calcium signaling in mesenchymal stem cells regulates aligned collagen matrix formation and vinculin tension. Proc Natl Acad Sci U S A 116: 1992-1997.

Godin LM, Suzuki S, Jacobs CR, Donahue HJ, Donahue SW (2007) Mechanically induced intracellular calcium waves in osteoblasts demonstrate calcium fingerprints in bone cell mechanotransduction. Biomech Model Mechanobiol 6: 391-398.

Gregory DE, Callaghan JP (2011) A comparison of uniaxial and biaxial mechanical properties of the annulus fibrosus: a porcine model. J Biomech Eng 133: 024503. DOI: $10.1115 / 1.4003327$.

Han S-K, Wouters W, Clark A, Herzog W (2012) Mechanically induced calcium signaling in chondrocytes in situ. J Orthop Res 30: 475-481.

Hayakawa K, Sato N, Obinata T (2001) Dynamic reorientation of cultured cells and stress fibers under mechanical stress from periodic stretching. Exp Cell Res 268: 104-114.

Hu F, Zhao Y, Hui Z, Xing F, Yang J, Lee I, Zhang X, Pan L, Xu J (2019) Regulation of intracellular Ca2+/ CaMKII signaling by TRPV4 membrane translocation during osteoblastic differentiation. Biophys Reports 5: 254-263.

Iatridis JC, Maclean JJ, Roughley PJ, Alini M (2006) Effects of mechanical loading on intervertebral disc metabolism in vivo. J Bone Jt Surg Am 88: 41-46.

Imuta Y, Koyama H, Shi D, Eiraku M, Fujimori T, Sasaki H (2014) Mechanical control of notochord 
morphogenesis by extra-embryonic tissues in mouse embryos. Mech Dev 132: 44-58.

Iu J, Santerre JP, Kandel RA (2014) Inner and outer annulus fibrosus cells exhibit differentiated phenotypes and yield changes in extracellular matrix protein composition in vitro on a polycarbonate urethane scaffold. Tissue Eng Part A 20: 3261-3269.

James SL, Abate D, Abate KH, Abay SM, Abbafati C, Abbasi N, Abbastabar H, Abd-Allah F, Abdela J, Abdelalim A, Abdollahpour I, Abdulkader RS, Abebe Z, Abera SF, Abil OZ, Abraha HN, Abu-Raddad LJ, Abu-Rmeileh NME, Accrombessi MMK, Acharya D, Acharya P, Ackerman IN, Adamu AA, Adebayo OM, Adekanmbi V, Adetokunboh OO, Adib MG, Adsuar JC, Afanvi KA, Afarideh M, Afshin A, Agarwal G, Agesa KM, Aggarwal R, Aghayan SA, Agrawal S, Ahmadi A, Ahmadi M, Ahmadieh H, Ahmed MB, Aichour AN, Aichour I, Aichour MTE, Akinyemiju T, Akseer N, Al-Aly Z, Al-Eyadhy A, Al-Mekhlafi HM, Al-Raddadi RM, Alahdab F, Alam K, Alam T, Alashi A, Alavian SM, Alene KA, Alijanzadeh M, Alizadeh-Navaei R, Aljunid SM, Alkerwi A, Alla F, Allebeck P, Alouani MML, Altirkawi K, AlvisGuzman N, Amare AT, Aminde LN, Ammar W, Amoako YA, Anber NH, Andrei CL, Androudi S, Animut MD, Anjomshoa M, Ansha MG, Antonio CAT, Anwari P, Arabloo J, Arauz A, Aremu O, Ariani F, Armoon B, Ärnlöv J, Arora A, Artaman A, Aryal KK, Asayesh H, Asghar RJ, Ataro Z, Atre SR, Ausloos M, Avila-Burgos L, Avokpaho EFGA, Awasthi A, Ayala Quintanilla BP, Ayer R, Azzopardi PS, Babazadeh A, Badali H, Badawi A, Bali AG, Ballesteros KE, Ballew SH, Banach M, Banoub JAM, Banstola A, Barac A, Barboza MA, Barker-Collo SL, Bärnighausen TW, Barrero LH, Baune BT, BazarganHejazi S, Bedi N, Beghi E, Behzadifar M, Behzadifar M, Béjot Y, Belachew AB, Belay YA, Bell ML, Bello AK, Bensenor IM, Bernabe E, Bernstein RS, Beuran M, Beyranvand T, Bhala N, Bhattarai S, Bhaumik S, Bhutta ZA, Biadgo B, Bijani A, Bikbov B, Bilano V, Bililign N, Bin Sayeed MS, Bisanzio D, Blacker BF, Blyth FM, Bou-Orm IR, Boufous S, Bourne R, Brady OJ, Brainin M, Brant LC, Brazinova A, Breitborde NJK, Brenner H, Briant PS, Briggs AM, Briko AN, Britton G, Brugha T, Buchbinder R, Busse R, Butt ZA, Cahuana-Hurtado L, Cano J, Cárdenas R, Carrero JJ, Carter A, Carvalho F, Castañeda-Orjuela CA, Castillo Rivas J, Castro F, Catalá-López F, Cercy KM, Cerin E, Chaiah Y, Chang AR, Chang HY, Chang JC, Charlson FJ, Chattopadhyay A, Chattu VK, Chaturvedi P, Chiang PPC, Chin KL, Chitheer A, Choi JYJ, Chowdhury R, Christensen H, Christopher DJ, Cicuttini FM, Ciobanu LG, Cirillo M, Claro RM, Collado-Mateo D, Cooper C, Coresh J, Cortesi PA, Cortinovis M, Costa M, Cousin E, Criqui MH, Cromwell EA, Cross M, Crump JA, Dadi AF, Dandona L, Dandona R, Dargan PI, Daryani A, Das Gupta R, Das Neves J, Dasa TT, Davey G, Davis AC, Davitoiu DV, De Courten B, De La Hoz FP, De Leo D, De Neve JW, Degefa MG, Degenhardt L, Deiparine S, Dellavalle RP, Demoz GT, Deribe K, Dervenis N,
Des Jarlais DC, Dessie GA, Dey S, Dharmaratne SD, Dinberu MT, Dirac MA, Djalalinia S, Doan L, Dokova K, Doku DT, Dorsey ER, Doyle KE, Driscoll TR, Dubey M, Dubljanin E, Duken EE, Duncan BB, Duraes AR, Ebrahimi H, Ebrahimpour S, Echko MM, Edvardsson D, Effiong A, Ehrlich JR, El Bcheraoui C, El Sayed Zaki M, El-Khatib Z, Elkout H, Elyazar IRF, Enayati A, Endries AY, Er B, Erskine HE, Eshrati B, Eskandarieh S, Esteghamati A, Esteghamati S, Fakhim H, Fallah Omrani V, Faramarzi M, Fareed M, Farhadi F, Farid TA, Farinha CSE, Farioli A, Faro A, Farvid MS, Farzadfar F, Feigin VL, Fentahun N, Fereshtehnejad SM, Fernandes E, Fernandes JC, Ferrari AJ, Feyissa GT, Filip I, Fischer F, Fitzmaurice C, Foigt NA, Foreman KJ, Fox J, Frank TD, Fukumoto T, Fullman N, Fürst T, Furtado JM, Futran ND, Gall S, Ganji M, Gankpe FG, Garcia-Basteiro AL, Gardner WM, Gebre AK, Gebremedhin AT, Gebremichael TG, Gelano TF, Geleijnse JM, Genova-Maleras R, Geramo YCD, Gething PW, Gezae KE, Ghadiri K, Ghasemi Falavarjani K, Ghasemi-Kasman M, Ghimire M, Ghosh R, Ghoshal AG, Giampaoli S, Gill PS, Gill TK, Ginawi IA, Giussani G, Gnedovskaya E V., Goldberg EM, Goli S, Gómez-Dantés H, Gona PN, Gopalani SV, Gorman TM, Goulart AC, Goulart BNG, Grada A, Grams ME, Grosso G, Gugnani HC, Guo Y, Gupta PC, Gupta R, Gupta R, Gupta T, Gyawali B, Haagsma JA, Hachinski V, Hafezi-Nejad N, Haghparast Bidgoli H, Hagos TB, Hailu GB, Haj-Mirzaian A, HajMirzaian A, Hamadeh RR, Hamidi S, Handal AJ, Hankey GJ, Hao Y, Harb HL, Harikrishnan S, Haro JM, Hasan M, Hassankhani H, Hassen HY, Havmoeller R, Hawley CN, Hay RJ, Hay SI, HedayatizadehOmran A, Heibati B, Hendrie D, Henok A, Herteliu C, Heydarpour S, Hibstu DT, Hoang HT, Hoek HW, Hoffman HJ, Hole MK, Homaie Rad E, Hoogar P, Hosgood HD, Hosseini SM, Hosseinzadeh M, Hostiuc M, Hostiuc S, Hotez PJ, Hoy DG, Hsairi M, Htet AS, Hu G, Huang JJ, Huynh CK, Iburg KM, Ikeda CT, Ileanu B, Ilesanmi OS, Iqbal U, Irvani SSN, Irvine CMS, Mohammed S, Islam S, Islami F, Jacobsen KH, Jahangiry L, Jahanmehr N, Jain SK, Jakovljevic M, Javanbakht $\mathrm{M}$, Jayatilleke AU, Jeemon $\mathrm{P}$, Jha RP, Jha V, Ji JS, Johnson CO, Jonas JB, Jozwiak JJ, Jungari SB, Jürisson M, Kabir Z, Kadel R, Kahsay A, Kalani R, Kanchan T, Karami M, Karami Matin B, Karch A, Karema C, Karimi N, Karimi SM, Kasaeian A, Kassa DH, Kassa GM, Kassa TD, Kassebaum NJ, Katikireddi SV, Kawakami N, Kazemi Karyani A, Keighobadi MM, Keiyoro PN, Kemmer L, Kemp GR, Kengne AP, Keren A, Khader YS, Khafaei B, Khafaie MA, Khajavi A, Khalil IA, Khan EA, Khan MS, Khan MA, Khang YH, Khazaei M, Khoja AT, Khosravi A, Khosravi MH, Kiadaliri AA, Kiirithio DN, Kim C Il, Kim D, Kim P, Kim YE, Kim YJ, Kimokoti RW, Kinfu Y, Kisa A, Kissimova-Skarbek K, Kivimäki M, Knudsen AKS, Kocarnik JM, Kochhar S, Kokubo Y, Kolola T, Kopec JA, Kosen S, Kotsakis GA, Koul PA, Koyanagi A, Kravchenko MA, Krishan K, Krohn KJ, Kuate Defo B, Kucuk Bicer B, Kumar GA, Kumar M, Kyu HH, Lad DP, Lad SD, Lafranconi A, Lalloo R, Lallukka T, 
Lami FH, Lansingh VC, Latifi A, Lau KMM, Lazarus J V., Leasher JL, Ledesma JR, Lee PH, Leigh J, Leung J, Levi M, Lewycka S, Li S, Li Y, Liao Y, Liben ML, Lim LL, Lim SS, Liu S, Lodha R, Looker KJ, Lopez AD, Lorkowski S, Lotufo PA, Low N, Lozano R, Lucas TCD, Lucchesi LR, Lunevicius R, Lyons RA, Ma S, Macarayan ERK, Mackay MT, Madotto F, Magdy Abd El Razek H, Magdy Abd El Razek M, Maghavani DP, Mahotra NB, Mai HT, Majdan M, Majdzadeh R, Majeed A, Malekzadeh R, Malta DC, Mamun AA, Manda AL, Manguerra H, Manhertz T, Mansournia MA, Mantovani LG, Mapoma CC, Maravilla JC, Marcenes W, Marks A, Martins-Melo FR, Martopullo I, März W, Marzan MB, Mashamba-Thompson TP, Massenburg BB, Mathur MR, Matsushita K, Maulik PK, Mazidi M, McAlinden C, McGrath JJ, McKee M, Mehndiratta MM, Mehrotra R, Mehta KM, Mehta V, Mejia-Rodriguez F, Mekonen T, Melese A, Melku M, Meltzer M, Memiah PTN, Memish ZA, Mendoza W, Mengistu DT, Mengistu G, Mensah GA, Mereta ST, Meretoja A, Meretoja TJ, Mestrovic T, Mezerji NMG, Miazgowski B, Miazgowski T, Millear AI, Miller TR, Miltz B, mini GK, Mirarefin M, Mirrakhimov EM, Misganaw AT, Mitchell PB, Mitiku H, Moazen B, Mohajer B, Mohammad KA, Mohammadifard N, Mohammadnia-Afrouzi M, Mohammed MA, Mohammed S, Mohebi F, Moitra M, Mokdad AH, Molokhia M, Monasta L, Moodley Y, Moosazadeh M, Moradi G, Moradi-Lakeh M, Moradinazar M, Moraga P, Morawska L, Moreno Velásquez I, Morgado-Da-Costa J, Morrison SD, Moschos MM, Mousavi SM, Mruts KB, Muche AA, Muchie KF, Mueller UO, Muhammed OS, Mukhopadhyay S, Muller K, Mumford JE, Murhekar M, Musa J, Musa KI, Mustafa G, Nabhan AF, Nagata C, Naghavi M, Naheed A, Nahvijou A, Naik G, Naik N, Najafi F, Naldi L, Nam HS, Nangia V, Nansseu JR, Nascimento BR, Natarajan G, Neamati N, Negoi I, Negoi RI, Neupane S, Newton CRJ, Ngunjiri JW, Nguyen AQ, Nguyen HT, Nguyen HLT, Nguyen HT, Nguyen LH, Nguyen M, Nguyen NB, Nguyen SH, Nichols E, Ningrum DNA, Nixon MR, Nolutshungu N, Nomura S, Norheim OF, Noroozi M, Norrving B, Noubiap JJ, Nouri HR, Nourollahpour Shiadeh M, Nowroozi MR, Nsoesie EO, Nyasulu PS, Odell CM, Ofori-Asenso R, Ogbo FA, Oh IH, Oladimeji O, Olagunju AT, Olagunju TO, Olivares PR, Olsen HE, Olusanya BO, Ong KL, Ong SK, Oren E, Ortiz A, Ota E, Otstavnov SS, øverland S, Owolabi MO, Mahesh PA, Pacella R, Pakpour AH, Pana A, Panda-Jonas S, Parisi A, Park EK, Parry CDH, Patel S, Pati S, Patil ST, Patle A, Patton GC, Paturi VR, Paulson KR, Pearce N, Pereira DM, Perico N, Pesudovs K, Pham HQ, Phillips MR, Pigott DM, Pillay JD, Piradov MA, Pirsaheb M, Pishgar F, Plana-Ripoll O, Plass D, Polinder S, Popova S, Postma MJ, Pourshams A, Poustchi H, Prabhakaran D, Prakash S, Prakash V, Purcell CA, Purwar MB, Qorbani M, Quistberg DA, Radfar A, Rafay A, Rafiei A, Rahim F, Rahimi K, Rahimi-Movaghar A, RahimiMovaghar V, Rahman M, Ur Rahman MH, Rahman MA, Rahman SU, Rai RK, Rajati F, Ram U, Ranjan P,
Ranta A, Rao PC, Rawaf DL, Rawaf S, Reddy KS, Reiner RC, Reinig N, Reitsma MB, Remuzzi G, Renzaho AMN, Resnikoff S, Rezaei S, Rezai MS, Ribeiro ALP, Robinson SR, Roever L, Ronfani L, Roshandel G, Rostami A, Roth GA, Roy A, Rubagotti E, Sachdev PS, Sadat N, Saddik B, Sadeghi E, Saeedi Moghaddam S, Safari H, Safari Y, Safari-Faramani R, Safdarian M, Safi S, Safiri S, Sagar R, Sahebkar A, Sahraian MA, Sajadi HS, Salam N, Salama JS, Salamati P, Saleem K, Saleem Z, Salimi Y, Salomon JA, Salvi SS, Salz I, Samy AM, Sanabria J, Sang Y, Santomauro DF, Santos IS, Santos JV, Santric Milicevic MM, Sao Jose BP, Sardana M, Sarker AR, Sarrafzadegan N, Sartorius B, Sarvi S, Sathian B, Satpathy M, Sawant AR, Sawhney M, Saxena S, Saylan M, Schaeffner E, Schmidt MI, Schneider IJC, Schöttker B, Schwebel DC, Schwendicke F, Scott JG, Sekerija M, Sepanlou SG, Serván-Mori E, Seyedmousavi S, Shabaninejad H, Shafieesabet A, Shahbazi M, Shaheen AA, Shaikh MA, Shams-Beyranvand M, Shamsi M, Shamsizadeh M, Sharafi H, Sharafi K, Sharif M, Sharif-Alhoseini M, Sharma M, Sharma R, She J, Sheikh A, Shi P, Shibuya K, Shigematsu M, Shiri R, Shirkoohi R, Shishani K, Shiue I, Shokraneh F, Shoman H, Shrime MG, Si S, Siabani S, Siddiqi TJ, Sigfusdottir ID, Sigurvinsdottir R, Silva JP, Silveira DGA, Singam NSV, Singh JA, Singh NP, Singh V, Sinha DN, Skiadaresi E, Slepak ELN, Sliwa K, Smith DL, Smith M, Soares Filho AM, Sobaih BH, Sobhani S, Sobngwi E, Soneji SS, Soofi M, Soosaraei M, Sorensen RJD, Soriano JB, Soyiri IN, Sposato LA, Sreeramareddy CT, Srinivasan V, Stanaway JD, Stein DJ, Steiner C, Steiner TJ, Stokes MA, Stovner LJ, Subart ML, Sudaryanto A, Sufiyan MB, Sunguya BF, Sur PJ, Sutradhar I, Sykes BL, Sylte DO, Tabarés-Seisdedos R, Tadakamadla SK, Tadesse BT, Tandon N, Tassew SG, Tavakkoli M, Taveira N, Taylor HR, TehraniBanihashemi A, Tekalign TG, Tekelemedhin SW, Tekle MG, Temesgen H, Temsah MH, Temsah O, Terkawi AS, Teweldemedhin M, Thankappan KR, Thomas N, Tilahun B, To QG, Tonelli M, ToporMadry R, Topouzis F, Torre AE, Tortajada-Girbés M, Touvier M, Tovani-Palone MR, Towbin JA, Tran BX, Tran KB, Troeger CE, Truelsen TC, Tsilimbaris MK, Tsoi D, Tudor Car L, Tuzcu EM, Ukwaja KN, Ullah I, Undurraga EA, Unutzer J, Updike RL, Usman MS, Uthman OA, Vaduganathan M, Vaezi A, Valdez PR, Varughese S, Vasankari TJ, Venketasubramanian N, Villafaina S, Violante FS, Vladimirov SK, Vlassov V, Vollset SE, Vosoughi K, Vujcic IS, Wagnew FS, Waheed Y, Waller SG, Wang Y, Wang YP, Weiderpass E, Weintraub RG, Weiss DJ, Weldegebreal F, Weldegwergs KG, Werdecker A, West TE, Whiteford HA, Widecka J, Wijeratne T, Wilner LB, Wilson S, Winkler AS, Wiyeh AB, Wiysonge CS, Wolfe CDA, Woolf AD, Wu S, Wu YC, Wyper GMA, Xavier D, Xu G, Yadgir S, Yadollahpour A, Yahyazadeh Jabbari SH, Yamada T, Yan LL, Yano Y, Yaseri M, Yasin YJ, Yeshaneh A, Yimer EM, Yip P, Yisma E, Yonemoto N, Yoon SJ, Yotebieng M, Younis MZ, Yousefifard M, Yu C, Zadnik V, Zaidi Z, Zaman S Bin, Zamani M, 
Zare Z, Zeleke AJ, Zenebe ZM, Zhang K, Zhao Z, Zhou M, Zodpey S, Zucker I, Vos T, Murray CJL (2018) Global, regional, and national incidence, prevalence, and years lived with disability for 354 diseases and injuries for 195 countries and territories, 1990-2017: a systematic analysis for the Global Burden of Disease Study (2017) Lancet 392: 1789-1858.

Jurand A (1974) Some aspects of the development of the notochord in mouse embryos. J Embryol Exp Morphol 32: 1-33.

Kawano S, Shoji S, Ichinose S, Yamagata K, Tagami M, Hiraoka M (2002) Characterization of Ca2+ signaling pathways in human mesenchymal stem cells. Cell Calcium 32: 165-174.

Kim MKM, Burns MJ, Serjeant ME, Séguin CA (2020) The mechano-response of murine annulus fibrosus cells to cyclic tensile strain is frequency dependent. JOR Spine 3: e21114. DOI: 10.1002/ jsp2.1114.

Koehl MAR, Quillin KJ, Pell CA (2000) Mechanical design of fiber-wound hydraulic skeletons: the stiffening and straightening of embryonic notochords. American Zoologist 40: 28-041.

Kovac JR, Chrones T, Sims SM (2008) Temporal and spatial dynamics underlying capacitative calcium entry in human colonic smooth muscle. Am J Physiol Gastrointest Liver Physiol 294: 88-98.

Koyama H, Fujimori T (2020) Isotropic expansion of external environment induces tissue elongation and collective cell alignment. J Theor Biol 496: 110248. DOI: 10.1016/j.jtbi.2020.110248.

Kurakawa T, Kakutani K, Morita Y, Kato Y, Yurube T, Hirata H, Miyazaki S, Terashima Y, Maeno K, Takada T, Doita M, Kurosaka M, Inoue N, Masuda K, Nishida K (2015) Functional impact of integrin a $5 b 1$ on the homeostasis of intervertebral discs: a study of mechanotransduction pathways using a novel dynamic loading organ culture system. Spine J 15: 417-426.

Liedtke W, Kim C (2005) Review Functionality of the TRPV subfamily of TRP ion channels: add mechano-TRP and osmo-TRP to the lexicon! Cell Mol Life Sci 62: 2985-3001.

Liedtke W, Choe Y, Martí-Renom MA, Bell AM, Denis CS, AndrejŠali, Hudspeth AJ, Friedman JM, Heller S (2000) Vanilloid receptor-related osmotically activated channel (VR-OAC), a candidate vertebrate osmoreceptor. Cell 103: 525-535.

Liedtke W, Friedman JM (2003) Abnormal osmotic regulation in trpv4-/- mice. Proc Natl Acad Sci U S A 100: 13698-13703.

Liu J, Wada Y, Katsura M, Tozawa H, Erwin N, Kapron CM, Bao G, Liu J (2018) Rho-associated coiled-coil kinase (ROCK) in molecular regulation of angiogenesis. Theranostics 8: 6053-6069.

Le Maitre CL, Frain J, Millward-Sadler J, Fotheringham AP, Freemont AJ, Hoyland JA (2009) Altered integrin mechanotransduction in human nucleus pulposus cells derived from degenerated discs. Arthritis Rheum 60: 460-469.
Mangos S, Liu Y, Drummond IA (2007) Dynamic expression of the osmosensory channel trpv4 in multiple developing organs in zebrafish. Gene Expr Patterns 7: 480-484.

Masuyama R, Vriens J, Voets T, Karashima Y, Owsianik G, Vennekens R, Lieben L, Torrekens S, Moermans K, Bosch A Vanden, Bouillon R, Nilius B, Carmeliet G (2008) TRPV4-mediated calcium influx regulates terminal differentiation of osteoclasts. Cell Metab 8: 257-265.

McCann MR, Tamplin OJ, Rossant J, Seǵuin CA (2012) Tracing notochord-derived cells using a Noto-cre mouse: implications for intervertebral disc development. Dis Model Mech 5: 73-82.

Mizoguchi F, Mizuno A, Hayata T, Nakashima K, Heller S, Ushida T, Sokabe M, Miyasaka N, Suzuki M, Ezura Y, Noda M (2008) Transient receptor potential vanilloid 4 deficiency suppresses unloading-induced bone loss. J Cell Physiol 216: 47-53.

Mochizuki T, Sokabe T, Araki I, Fujishita K, Shibasaki K, Uchida K, Naruse K, Koizumi S, Takeda M, Tominaga M (2009) The TRPV4 cation channel mediates stretch-evoked $\mathrm{Ca}^{2+}$ influx and atp release in primary urothelial cell cultures. J Biol Chem 284: 21257-21264.

Morrell AE, Brown GN, Robinson ST, Sattler RL, Baik AD, Zhen G, Cao X, Bonewald LF, Jin W, Kam LC, Guo XE (2018) Mechanically induced Ca2+ oscillations in osteocytes release extracellular vesicles and enhance bone formation. Bone Res 6: 6. DOI: 10.1038/s41413-018-0007-x.

Muramatsu S, Wakabayashi M, Ohno T, Amano K, Ooishi R, Sugahara T, Shiojiri S, Tashiro K, Suzuki Y, Nishimura R, Kuhara S, Sugano S, Yoneda T, Matsuda A (2007) Functional gene screening system identified TRPV4 as a regulator of chondrogenic differentiation J Biol Chem 282: 32158-31267.

Nam S, Gupta VK, Lee H pyo, Lee JY, Wisdom KM, Varma S, Flaum EM, Davis C, West RB, Chaudhuri O (2019) Cell cycle progression in confining microenvironments is regulated by a growth-responsive TRPV4-PI3K/Akt-p27Kip1 signaling axis. Sci Adv 5: eaaw6171. DOI: 10.1126/ sciadv.aaw6171.

Neidlinger-Wilke C, Galbusera F, Pratsinis H, Mavrogonatou E, Mietsch A, Kletsas D, Wilke HJ (2014) Mechanical loading of the intervertebral disc: from the macroscopic to the cellular level. Eur Spine J 23 Suppl 3: S333-S343.

Neidlinger-Wilke C, Würtz K, Liedert A, Schmidt C, Börm W, Ignatius A, Wilke HJ, Claes L (2005) A three-dimensional collagen matrix as a suitable culture system for the comparison of cyclic strain and hydrostatic pressure effects on intervertebral disc cells. J Neurosurg Spine 2: 457-465.

Nettles DL, Richardson WJ, Setton LA (2004) Integrin expression in cells of the intervertebral disc. J Anat 204: 515-520.

O'Conor CJ, Leddy HA, Benefield HC, Liedtke WB, Guilak F (2014) TRPV4-mediated 
mechanotransduction regulates the metabolic response of chondrocytes to dynamic loading. Proc Natl Acad Sci 111: 1316-1321.

Ochsenbein RM, Inaebnit SP, Luethy CM, Wiesmann UN, Oetliker OH, Honegger UE (1999) Differential regulation of bradykinin receptor density, intracellular $\mathrm{Ca} 2+$, and prostanoid release in skin and foreskin fibroblasts. Effects of cell density and interleukin-1 $\alpha$. Br J Pharmacol 127: 583-589.

Paavola LG, Wilson DB, Center EM (1980) Histochemistry of the developing notochord, perichordal sheath and vertebrae in Danforth's shorttail (Sd) and normal C57BL/6 mice. J Embryol Exp Morphol 55: 227-245.

Pairet N, Mang S, Fois G, Keck M, Kühnbach M, Gindele J, Frick M, Dietl P, Lamb DJ (2018) TRPV4 inhibition attenuates stretch-induced inflammatory cellular responses and lung barrier dysfunction during mechanical ventilation. PLoS One 13: e0196055. DOI: 10.1371/journal.pone.0196055.

Phan MN, Leddy HA, Votta BJ, Kumar S, Levy DS, Lipshutz DB, Lee S, Liedtke W, Guilak F (2009) Functional characterization of TRPV4 as an osmotically sensitive ion channel in articular chondrocytes. Arthritis Rheum 60: 3028-3037.

Raizman I, Amritha JN, Croos D, Pilliar R, Kandel RA (2010) Calcium regulates cyclic compressioninduced early changes in chondrocytes during in vitro cartilage tissue formation. Cell Calcium 48: 232-242.

Reinhard E, Yokoe H, Niebling KR, Allbritton NL, Kuhn MA, Meyer T (1995) Localized calcium signals in early zebrafish development. Dev Biol 170: 50-61.

Ryskamp DA, Frye AM, Phuong TTT, Yarishkin O, Jo AO, Xu Y, Lakk M, Iuso A, Redmon SN, Ambati B, Hageman G, Prestwich GD, Torrejon KY, Križaj D (2016) TRPV4 regulates calcium homeostasis, cytoskeletal remodeling, conventional outflow and intraocular pressure in the mammalian eye. Sci Rep 6: 30583. DOI: $10.1038 /$ srep30583.

Sahu SU, Visetsouk MR, Garde RJ, Hennes L, Kwas C, Gutzman JH (2017) Calcium signals drive cell shape changes during zebrafsh midbrain-hindbrain boundary formation. Mol Biol Cell 28: 875-882.

Schatz O, Golenser E, Ben-Arie N (2005) Clearing and photography of whole mount $\mathrm{X}$-gal stained mouse embryos. Biotechniques 39: 650-656.

Setton LA, Chen J (2004) Cell mechanics and mechanobiology in the intervertebral disc. Spine (Phila Pa 1976) 29: 2710-2723.

Sharma S, Goswami R, Zhang DX, Rahaman SO (2019) TRPV4 regulates matrix stiffness and TGF $\beta 1-$ induced epithelial-mesenchymal transition. J Cell Mol Med 23: 761-774.

Shirazi-Adl SA, Shrivastava SC, Ahmed AM (1984) Stress analysis of the lumbar disc-body unit in compression. A three-dimensional nonlinear finite element study. Spine (Phila Pa 1976) 9: 120-134.

Strotmann R, Harteneck C, Nunnenmacher K, Schultz G, Plant TD (2000) OTRPC4, a nonselective cation channel that confers sensitivity to extracellular osmolarity. Nat Cell Biol 2: 695-702.
Suzuki T, Notomi T, Miyajima D, Mizoguchi F, Hayata T, Nakamoto T, Hanyu R, Kamolratanakul P, Mizuno A, Suzuki M, Ezura Y, Izumi Y, Noda M (2013) Osteoblastic differentiation enhances expression of TRPV4 that is required for calcium oscillation induced by mechanical force. Bone 54: 172-178.

Thodeti CK, Matthews B, Ravi A, Mammoto A, Ghosh K, Bracha AL, Ingber DE (2009a) TRPV4 channels mediate cyclic strain-induced endothelial cell reorientation through integrin-to-integrin signaling. Circ Res 104: 1123-1130.

Thodeti CK, Matthews B, Ravi A, Mammoto A, Ghosh K, Bracha AL, Ingber DE (2009b) TRPV4 channels mediate cyclic strain-induced endothelial cell reorientation through integrin-to-integrin signaling. Circ Res 104: 1123-1130.

Trompeter N, Gardinier JD, Debarros V, Boggs M, Hurd L, Duncan RL, Duncan R (2020) Insulin-like growth factor-1 regulates the mechanosensitivity of chondrocytes by modulating TRPV4. Biorxiv. DOI: 10.1101/2020.03.10.985713.

Tsuruwaka Y, Shimada E, Tsutsui K, Ogawa T (2017) Ca2+ dynamics in zebrafish morphogenesis. PeerJ 2017: e2894. DOI: 10.7717/peerj.2894.

Verkhratsky A, Orkand RK, Kettenmann H (1998) Glial calcium: homeostasis and signaling function. Physiol Rev 78: 99-141.

Videman TA, Nurminen MA TJ (1990) Volvo Award in clinical sciences. Lumbar spinal pathology in cadaveric material in relation to history of back pain, occupation, and physical loading. Spine (Phila Pa 1976) 15: 728-740.

Wallingford JB, Fraser SE, Harland RM (2002) Convergent extension: the molecular control of polarized cell movement during embryonic development. Dev Cell 2: 695-706.

Walsh AJL, Lotz JC (2004) Biological response of the intervertebral disc to dynamic loading. J Biomech 37: 329-337.

Walter BA, Purmessur D, Moon A, Occhiogrosso J, Laudier DM, Hecht AC, Iatridis JC (2016) Reduced tissue osmolarity increases TRPV4 expression and pro-inflammatory cytokines in intervertebral disc cells. Eur Cells Mater 32: 123-136.

Watanabe H, Vriens J, Prenen J, Droogmans G, Voets T, Nilius B (2003) Anandamide and arachidonic acid use epoxyeicosatrienoic acids to activate TRPV4 channels. Nature 424: 434-438.

Webb SE, Miller AL (2000) Calcium signalling during zebrafish embryonic development. BioEssays 22: 113-123.

Woods A, Wang G, Beier F (2007) Regulation of chondrocyte differentiation by the actin cytoskeleton and adhesive interactions. J Cell Physiol 213: 1-8.

Wuertz K, Urban JPG, Klasen J, Ignatius A, Wilke H-J, Claes L, Neidlinger-Wilke C (2007a) Influence of extracellular osmolarity and mechanical stimulation on gene expression of intervertebral disc cells. J Orthop Res 25: 1513-1522.

Wuertz K, Urban JPG, Klasen J, Ignatius A, Wilke H-J, Claes L, Neidlinger-Wilke C (2007b) Influence of 
extracellular osmolarity and mechanical stimulation on gene expression of intervertebral disc cells. J Orthop Res 25: 1513-1522.

Wuertz K, Godburn K, MacLean JJ, Barbir A, Donnelly JS, Roughley PJ, Alini M, Iatridis JC (2009) In vivo remodeling of intervertebral discs in response to short- and long-term dynamic compression. J Orthop Res 27: 1235-1242.

Xiao Y, Bhaskaran A, Scott H, Ardekani S, Xu J, Mohideen U, Kern TS, Ghosh K (2016) Rho/ROCKmediated retinal endothelial stiffening impairs TRPV4 signaling and promotes diabetic retinal inflammation. Invest Ophthalmol Vis Sci 57: 32203220.

Yavropoulou MP, Yovos JG (2016) The molecular basis of bone mechanotransduction. J Musculoskelet Neuronal Interact 16: 221-236.

Ye L, Kleiner S, Wu J, Sah R, Gupta RK, Banks AS, Cohen P, Khandekar MJ, Boström P, Mepani RJ, Laznik D, Kamenecka TM, Song X, Liedtke W, Mootha VK, Puigserver P, Griffin PR, Clapham DE, Spiegelman BM (2012) TRPV4 is a regulator of adipose oxidative metabolism, inflammation, and energy homeostasis. Cell 151: 96-110.

Ziegler ME, Jin YP, Young SH, Rozengurt E, Reed EF (2012) HLA class I-mediated stress fiber formation requires ERK1/2 activation in the absence of an increase in intracellular $\mathrm{Ca} 2+$ in human aortic endothelial cells. Am J Physiol Cell Physiol 303: C872882

\section{Discussion with Reviewer}

Reviewer: You have a different culture for the mechanical stimulation as compared to the rest of in vitro work (silicone $v s$. tissue culture plastic). How much would you think this impacts cellular behaviour and ability to compare different experiments when using CTS and agonists?

Authors: The reviewer is correct in highlighting that the effects of culture substrate on cell phenotype were not directly assessed in the present study. However, in a recent publication characterising the CTS culture system, Kim et al. (2020) demonstrated that AF cells cultured on tissue culture plastic and silicone membranes for CTS show similar expression of AF and fibroblast-associated markers (i.e. Col1a1, Gdf10, Pax1, Cilp, Acta2, Fap). As such, we are confident that differences in the culture platform do not overtly alter cell phenotype. However, differences in substrate stiffness can modulate the cellular mechano- response and as such the findings from these distinct experiments were presented separately. Also, the cells used represented a heterogeneous mixture of inner and outer AF cells, due to the limitations of working with small murine IVD tissues. Based on the differential expression of Trpv4 in inner and outer AF tissues, the effects of mechanical activation and pharmacological modulators of TRPV4 may be diluted in this mixed population as compared to using a homogeneous population of cells with robust expression of Trpo4.

The model systems used have important limitations and, as such, ongoing studies are focussing on the use of in vivo models to circumvent some of these limitations.

Reviewer: How would you explain Trpv4 expression being predominantly in the tail tip? What would you think does that mean for human?

Authors: During development, notochord elongation occurs in caudo-cranial direction, whereas mesenchymal condensation and notochord segmentation occur in cranio-caudal direction. The condensed mesenchyme and segmenting notochord later form the AF and NP, respectively. Hence, the IVD tissue formation, development and maturation also differ temporally across the spine (craniocaudally). As such, it is tempting to speculate that coccygeal IVDs found at the tail tip are slightly less mature than IVD tissues found in the lumbar and thoracic regions. Along with differences in mechanical environment, this temporal difference in tissue patterning, development and maturation may explain differential expression of Trpv4 in specific spine regions.

The implications of studies using mouse models to human physiology is an important question. It is difficult to translate the findings of Trpv4 expression profile in caudal IVDs to understand or make speculations on human disc biology. The study focused on outlining when and where Trpv4 was expressed in the murine IVD during development. Building upon these findings, future studies will use knockout mouse models to further investigate the role of TRPV4 in the context of ageing and injury. Of course, findings from the present study will require validation in human tissues to understand implications for human IVD health.

Editor's note: The Guest Editor responsible for this paper was Zhen Li. 